(C) 1983 ISIJ

\title{
溶銑予備処理における物理化学の発展と課題
}

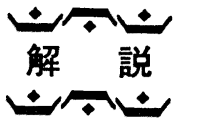

徳 田 昌 則*

\section{A Brief History and Some Topics of the Physical Chemistry in the Pretreatment of Hot Metal}

金属を酸化物鉱石から還元して得るためには大量のエ ネルギーを要し, 一方, 目的とする製品の質は多岐にわ たる、したがつて，製鉄法が粗金属を得る製錬工程と所 要の質の製品を得る精錬工程とに分離し，エネルギー． ミニマムの追求と製品に対する要求を独立して達成させ る間接製鋼法として発展したのは自然であつた．溶銑予 備処理法は精鍊工程の機能を強化するためにさらに追加 されたプロセスであり，その歴史は遠くコークス高炉の 摇籃期にまでさかのぼることができる1).

本稿では, いくつかの教科書(1) 五を参考にして，とく に脱りん処理について流れ1を追いつつその底流をなす 物理化学的概念の発展を跡ゔけ, その上で, 現状の知見 と問題点の整理を試みた。

\section{1. 溶銑脱りん法小史}

溶銑中のりんを意図的に炭素に優先して除去するとい う意味での溶銑脱りんの歴史はそれ程古くはないが，溶 銑もしくは高炭素鉄を酸化処理する過程で, かなりの脱 炭が進行する以前に, りんが結果的に除去されるといら 意味での溶銑脱りんプロセスは, かなり古くまでさかの ぼることができる1).

\section{$1 \cdot 1$ 前史一スラグの役割についての認識の発展}

14 世紀以前のレン炉やスティックオーフェン炉に代 表される直接製鉄法では, $\mathrm{FeO}$ 分の高いファヤライト 系スラグを作ることにより，スラグを低融点化して金属 鉄とガング成分を分離していた. 低温還元，木炭の使用 により，PやSは比較的少なかつた（鉱石を選んで製鍊 した).

水車等の使用により送風技術が発展し, 送風が強化さ れるにつれ炉内は高温になり, $\mathrm{FeO}$ の還元が進んでス ラグ融点が高くなるため, $\mathrm{FeO}$ を一部代替する何らか の溶剤がくふうされるに至つた．アグリコラ著「デ・レ. メタリカ」(1556 年)によれば，レン怩などの操業に関連 して「必要があれば，溶剤として石灰石を添加する」と 記述され，石灰石の効果が注目されていたとみられる.

\section{Masanori ToKuDA}

\section{1 .2 高炉法（間接法）の確立期}

15 世紀前半に出現した高炉法は 16〜17 世紀に広く 定着したが，高炉法による銑鉄の製造を円滑に行うに は, 強力な送風技術の確立と共に，スラグを低融点化す るための装入物配合法の普及が不可欠であり, 溶剤とし ての石灰石もしくは焼石灰の役割が確立されていつた。

スウェーデンボルグは最古の鉄冶金教科書といわれる $\lceil\mathrm{De}$ Ferro」(1734 年) の中で, 高炉作業に関連して, スラグの役割, 石灰石の役割, 鉱石種に応じた配合比, 炉況とスラグの性質（流動性，色調，凝固時の挙動など） の関係などに言及している. 高炉の高温還元のために粗 金属としての溶銑は原料に応じて多様な不純物を含むよ らになり，その中で泠脆鉄が注目されるよらになる.

高炬で作られた銑鉄は精錬炉へ送られた．ここでは， スラグで裏張りされた炉床部に木炭を積み重ね, 銑鉄を 装入して空気を吹き込み半溶鉄をこねまわしながら徐々 に脱炭を行いつつ,ルッペや鋼を得た。この作業でスラ グの性質と量は重要であり, 溶剤, 不純物除去剤掞よび 保護層として役立つた。 また冷脆鉄と熱脆鉄で用いるス ラグの種類が使い分けられた.

1730 年代にダービー父子によるコークス高炬技術が 確立すると, 脱硫がますます重要な課題となり, 石灰石 の高炉に护ける脱硫効果が議論されるに至つている (1760).

硫黄と熱脆性との 関連は, 18 世紀 1780 年代に至つ て明らかにされた.

\section{3 パドル法と予備精錬炬一溶銑脱りんの第 1 期}

18 世紀には，コークス高炉法は確立されたが，精鍊 炬では鉄と炭材を直接接触させて処理するために，炭材 としては木炭が不可欠で, コークスを用いた精錬法は硫 黄を除去できずすべて失敗した.

精鍊炬にコークスを使う試みは反射炉法の採用により 発展し, ヘンリー・コートのパドル法の発明につながつ た. パドル法は木炭精錬炉からの解放と, より大量生産 を可能とした. 
一方，高炉では，硫黄のより少ない鉄を作るには，ね ずみ銑を作るべきことが広く認識され，その結果，精錬 炉では, $\mathrm{Si}$ 増のために粘性の高いスラグを大量に処理せ ざるを得なくなり，精錬に長時間を要して，製鋼屋は頭 を痛めた。

パドル炉での精錬時間の短縮と精錬作業の軽減をはか るために，ねずみ銑を予備精鍊炬で酸化性雾团気で溶解 し，白鉄化する方法が普及した ${ }^{5)}$. この予備精鍊の段階 で脱珪が行われると同時に脱りんが一部進行した。

19 世紀の初めには，スラグの分析の 重要性が指摘さ れベルッェリウスによる酸・塩基概念の発展, カルステ ンによる高 $\mathrm{FeO}$ スラグと低 $\mathrm{FeO}$ スラグの役割の解明 が進んだ. 一方, 経験的にパドル炬に括ける反応促進剂 の開発が種々試みられ，1830 年代には，陶土，酸化性 スラグ $\mathrm{NaCl}\left(+\mathrm{K}_{2} \mathrm{CO}_{3}+\mathrm{CaO}\right), \mathrm{NaCl}+\mathrm{CaCO}_{3}+\mathrm{KNO}_{3}$, $\mathrm{MnCl}_{2}+\mathrm{CaCl}_{2}$ などの特許が現れている。これらはガス 発生に上る精錬促進が主体であるが，間接的には脱りん 効果も期待されていたようである.

な抢，パドル法に打いては，「脱りんは主として銑鉄 が溶け終わつて，これを櫬拌し始めるときに進行し，そ の後のプロセスでは逆に再びスラグからりんが還元され る」といら現象が認識されるに至つた.

\section{4 ベッセマー転炉の発明一溶銑脱りんの第 2 期}

ベッセマー転炉の発明により，溶鋼の大量生産の時代 が幕を開けたが，脱硫，脱りんを行らことができないた めに，その適用は低硫，低り几鉱石に制約されていた。

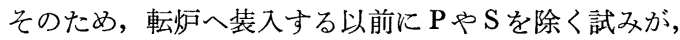
ベッセマー法の 発明からトーマス法の 発明に至るほぼ 20 年間に極めて精力的に行われた.

$\mathrm{P}$ を選鉱法で除去する試みは一部の鉱石については成 功を收めた。

つづいて，Pを高炉の段階で除く試みが，蛍石や塩化 物などを羽口から吹き込むなどの方法により，種々検討 されたが，すべて失敗㴆し，低り几鉱石を用いるしか 方法のないことが確認された。この間，Mnを含む溶剂 と塩基度の高いスラグが高炉での脱硫に有効であること も確認された。

こうして，Pを除く試みは溶銑の段階に集中した。一 つの流れは, 溶銑の一般的な予備精錬法で, 種々の添加 物を溶銑と接触させ，PやS 除去するものであつた.

酸化鉄や圧延スケールと塩化物の混合物, 蛍石と酸化鉄 粉, 蛍石々 氷晶石, $\mathrm{KCl}+\mathrm{NaCl}, \mathrm{NH}_{4} \mathrm{Cl}, \mathrm{NH}_{4} \mathrm{CN}$,

$\mathrm{CaCl}_{2}, \mathrm{Na}_{2} \mathrm{CO}_{3}+\mathrm{CaO}, \mathrm{Kl}$, などの予備精鍊用添加物 がくふらされ，特許が取られている。これらの添加物を 細粉状にして溶銑中に吹き込み，あるいは，それらの混 合物で作られた層の中や上に溶銑を流すといら方法で反 応を行わせた，高炉に直結した走行式炉床に空気あるい は過熱水蒸気を吹き込む処理法も検討されている。 しか し，これらの方法はほとんどの場合コストが高く，広く
工業化されるまでには至らなかつた。

もら一つの流れは, 溶銑の脱りんに狙いを集中した予 備精錬法で，これは一定の工業化に成功した.

Lowthian BELL は, 1877 年に, 脱炭の起こる前の低 温で酸化鉄により P方が除去されるといらパドル法でよく 知られていた経験に基づいて, 溶銑脱りん法を開発し た．溶銑を摇り籠式の摇動槽にハンマースケール，精錬 涬，鉄鉱石などとともに装入，加熱し，60〜80 回/ $\mathrm{min}$ の振り子運動により反応させた．その後， $\mathrm{P}_{2} \mathrm{O}_{5}$ を含む スラグは排涬され，浄化銑はパドル炬に移された．Pは $1.5 \rightarrow 0.22 \%$, Si が $1.8 \rightarrow 0.05 \%$ に低下した.

一方, フリードリッヒ・クルップ商会も 1877 年に溶 銑脱りん法の特許を取つた。 これは，鉄の壁の内側を Mn の豊富な 鉄鉱石で内張りしたペルノー旋回炉に, 高炉から $\mathrm{Mn}$ の高い、溶銑 $5 \sim 8 \mathrm{t}$ を装入し, 炬が施回 する間，酸化鉄に富んだ物質（たとえば，銑鉄 100 に 対して, 石灰 1 ，鉄鉱石十圧延涬 14)を添加するもの で，1 回の脱りん作業には 15 20 min かかつた. 脱り んされたメタルは Si の多い銑鉄と配合して,ベッセマ 一転炉またはシーメンス・マルチン炉で精鍊した. 12 基 の SM 怇に対して, 浄化炬は 1 基で十分であつた. こ の方法は工業化後 2 年で, ドイッではトーマス法に駆逐 されてしまつたが, 北アメリカに導入されたものは，ク ルップの洗浄法 (Wasch Prozess) と呼ばれ, 1890 年に おいても操業されていた．脱りん率は 70 85\% で 0.1 〜 $0.5 \%$ のPが $0.02 \%$ まで除去された.

その他にもいくつか脱りん法の提案があつたが，いず れも 1878 年のトーマス転炉法, それに続く塩基性平炉 法という，塩基性耐火物の使用により脱りん，脱硫の問 題を脱炭とともに同一炉内で処理するという方法の出現 により駆逐されてしまつた。

\section{$1.5 \mathrm{LD}$ 転炉の導入期一溶鉄脱りんの第 3 期}

塩基性平炉法が隆盛の時期には, 脱珠は別にして, 溶 銑脱りん介入の 余地は無かつた. それは, 平炉操業で は, 装入 $\rightarrow$ 溶解 $\rightarrow$ 溶け落ちに至る比較的低温の期間に石 灰を加穴, 脱珪, 脱りんを優先的に進めることができる 上に, 溶け落ち後脱炭期に入る前に, 除涬 (flushing) が 容易にできたためである。このため，溶銑中Pが $0.3 \%$ 以上でも, 溶け落ち時のPは $0.1 \%$ 以下になり,なお 精鍊期に十分の脱りんを行い得た.

こうして，LD 転炬導入期には, 平炉涬の高炬への 回収使用もあつて, 平炉銑の P は $0.2 \%$ をはるかに越 えていた，その上，先行きはいつそう高りんとなること が予測されたために，LD 炬での脱りん能力にはかな りの不安があつた.

このため, 導入に先立つて, 試験転炉による脱りん法 の検討とともに, 予備脱りんの試験も行われた ${ }^{6}$. 取鍋 に酸素と石灰, 蛍石を吹き付け, Pを $0.35 \rightarrow 0.07 \%$ 程 度にすることができたが, 操作が複雑なこと, Si が完 
全に消耗するなどの問題により，日の目を見るに至らな かつた.

現実には，LD 炉の操業努力と平炉および転炉涬の 高炉への回収使用の中止により，0.18〜0.15\% Pを維持 しさらに原料鈗石の低りん化による溶銑中Pのいつそう の低下により, 溶銑脱りんの必要性は無くなつた.

\section{6 溶銑処理プロセスの確立期}

高度成長期の末期, 転炉スラグの廃棄場所の確保難が 予想されるに至り, その対策が重要な課題となつた. そ の最も簡明な解決策は転炉スラグ発生量の低減であっ た. 一方では, 転炉の計算機制御による的中率がスラグ 量の圧縮により大きく向上し得ること, 脱ガス処理比や 連鋳比率の増大に伴ら出鋼温度上昇によつて復りんや炉 壁損傷などが深刻な問題になつたことなどにより，スラ グ量の低減は焦眉の課題となつた. こうして, 脱珪と脱 りんを目的とする予備処理が，溶銑処理プロセスとし て, 高品質と制御性を重視する新しい製鋼体系の中で明 確に位置付けられるに至つた。

このような，新しい製鋼体系への編成に向けての動き は, 基礎研究面にも大きな刺激を与え, 物理化学的研究 の対象や手法は従来とは異なる方向にも拡大され, 多彩 な成果をもたらしつつある.

\section{2. 物理化学的概念の発展}

約 100 年前に著された Lowthian_BELL の教科書2）を みると，溶銑に空気を吹き付ける予借処理により，90\% 以上の脱珪と $50 \%$ 程度の脱炭を行つて, パドリング・プ 口セスの操業時間を短縮すると同時に, 効果的な脱りん が可能となることが記述されている. 化学反応式は示さ れていないが，スラグ, メタル, ガス各相の化学分析と 物質収支に基づいて反応経過の考察がなされている.

19 世紀の後半に熱力学の 諸法則や基本的概念が確立 され，19〜20 世紀にかけては技術の各分野でその適用 が試みられた，その鉄治金に拈ける輝かしい成果が，30 を過ぎたばかりの少壮の $H$. SCHENCK により，ほぼ 50 年前に刊行された

この著書で脱硫と脱りん反応がどのように扱われてい

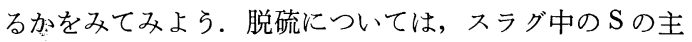
な存在形態を $\mathrm{CaS}$ と $\mathrm{MnS}$ と考え,

$\mathrm{CaO}+\mathrm{FeS}=\mathrm{FeO}+\mathrm{CaS}$

$\mathrm{Mn}+\mathrm{FeS}=\mathrm{Fe}+\mathrm{MnS}$

の各反応の平衡を基礎に $\mathrm{S}$ の平衡分配比と到達分配比を 比較している．製鋼炬での脱硫に有利な条件として，ス ラグ中の $\mathrm{Fe}$ と $\mathrm{SiO}_{2}$ が少ないこと, また有効な $\mathrm{CaO}$ $(\Sigma \mathrm{CaO})^{\prime}=(\Sigma \mathrm{CaO})-1.57\left(\Sigma \mathrm{P}_{2} \mathrm{O}_{5}\right)$ と $\mathrm{MnO}$ が高い ことを挙げている. また脱りんについては, 最新の成果 として, 次の平衡定数の式を紹介している.

$\log K=\left[\Sigma \mathrm{P}^{2}(\Sigma \mathrm{Fe})^{5} \mathrm{~B}^{\prime 3} /\left(\Sigma \mathrm{P}_{2} \mathrm{O}_{5}\right)=-24000 / T+\right.$ 11.62

$$
\begin{aligned}
& \text { ここに } \\
& \quad \mathrm{B}^{\prime}=0.01\left[(\Sigma \mathrm{GaO})-0.93\left(\Sigma \mathrm{SiO}_{2}\right)-1.18\left(\Sigma \mathrm{P}_{2} \mathrm{O}_{5}\right)\right]
\end{aligned}
$$

$[\Sigma \mathrm{P}]$ は溶鉄中の $\% \mathrm{P},(\Sigma \mathrm{Fe})$ はスラグ中の $\mathrm{T} . \mathrm{Fe}$ である。[ $\Sigma \mathrm{P}]$ は溶鉄中の $\mathrm{P}$ が元素状 $\mathrm{P}$ と化合物 $\mathrm{Fe}_{3} \mathrm{P}$ の 2 形態で存在し，その総和であることを示す.

現在, 脱硫脱りん反応に打ける分配比の総括的表現を 次のよらに与えることができる.

$$
\log L_{\mathrm{S}}=\log C_{\mathrm{S}^{2-}} / K_{\mathrm{S}}+\log f_{\mathrm{S}}-1 / 2 \log \left(P_{\mathrm{O}_{2}}\right)
$$

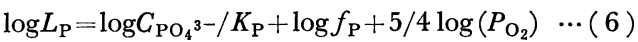
ここに, $C_{\mathrm{S}^{2-}}{ }^{2-}$ または $C_{\mathrm{PO}_{4}{ }^{3}-}$ はサルファイド，また はフォスフェート・キペシティ $(2 \cdot 4$ で詳述 $), K_{\mathrm{S}}$, $K_{\mathrm{P}}$ はおのおの $1 / 2 \mathrm{~S}_{2}=\underline{\mathrm{S}}, 1 / 2 \mathrm{P}_{2}=\mathrm{P}$ の平衡定数, $f_{\mathrm{S}}$, $f_{\mathrm{P}}$ は $\mathrm{S} ， \mathrm{P}$ の活量係数でこれらはすべて温度の関数で ある. $\left(P_{\mathrm{O}_{2}}\right)$ はスラグーメタル界面の酸素分圧である.

以下に (5)，（6)のような表現に至る過程をらり返つ てみたい.

\section{$\mathbf{2 \cdot 1}$ 塩基の主役の交替}

酸性および塩基性酸化物の規定は元素記号を初めて導 入したといわれる BERZELIUS によつてなされた7)， $\mathrm{SiO}_{2}$ が代表的な酸で，これと容易に結合して低融点を作る酸 化物が塩基であり， $\mathrm{FeO}$ が代表的塩基と考えられた。

パドル法では鉄鈗石で内張りした炉中で銑鉄を溶かし スケールを加えて $\mathrm{Si} ， \mathrm{P}, \mathrm{C}$ を酸化除去する. スラグ は高 $\mathrm{FeO}$ で $\mathrm{Si}$ と怶を酸性化 (acidify) する. $\mathrm{SiO}_{2}$ が $30 \%$ を超えると足の酸性化は困難になるので，脱珪 を目的にした予備処理が普及することになつた．表 1 ， 2 に, 予備処理を含めたパドル法におけるメタルとスラ グの成分変化の 例を示した ${ }^{8)}$. パドル法のスラグは高 $\mathrm{FeO}$, 低 $\mathrm{CaO}$ で脱りんが進んでいること, M.Feの混 入度が極めて高いことが理解できる.

ベッセマー転炉法と Mn 脱酸法が開発されて，良質 の鋼の量産の道が開かれたが，脱りんが出来ないため

表 1 メタル組成の変化の例8)

\begin{tabular}{|c|c|c|c|c|c|}
\hline \multirow{2}{*}{$\%$} & \multirow{2}{*}{\multicolumn{2}{|c|}{$\begin{array}{c}\text { 予備処理炬シンダー } \\
\text { Clarence* }^{*} \text { Bowling* }\end{array}$}} & \multicolumn{2}{|c|}{ パドル炉シンダー } & \multirow{2}{*}{ ベッセマー法 } \\
\hline & & & 人力** & 機械力** & \\
\hline $\mathrm{SiO}_{2}$ & 26.41 & 33. 33 & 16. 53 & 14. 17 & 80.84 \\
\hline $\mathrm{Al}_{2} \mathrm{O}_{3}$ & 2. 47 & 5. 75 & 1.04 & 1.76 & 3. 40 \\
\hline $\mathrm{CaO}$ & 2. 20 & 1. 19 & 0.70 & 0.25 & 1. 32 \\
\hline $\mathrm{MgO}$ & 0.24 & 0.50 & - & 0.42 & - \\
\hline $\mathrm{FeO}$ & 57.85 & 55.11 & 66.23 & 59. 14 & 8. 36 \\
\hline $\mathrm{Fe}_{2} \mathrm{O}_{3}$ & 2. 57 & - & - & 20.94 & - \\
\hline $\mathrm{MnO}$ & 3. 90 & 2. 71 & 4. 90 & 1. 21 & 6.04 \\
\hline & 0.05 & 0.17 & 2. 48 & 0.33 & - \\
\hline $\mathrm{P}_{2} \mathrm{O}_{5}$ & 4. 14 & 2.26 & 3. 80 & 1. 20 & $\sim 0$ \\
\hline 計 & 99.83 & 101.02 & 100 & 99. 42 & 99.86 \\
\hline M. $\mathrm{Fe}$ & 42.28 & 42.86 & 55.83 & 60.65 & - \\
\hline
\end{tabular}

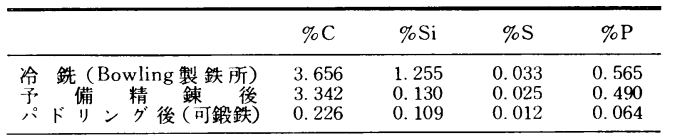

表 2 スラグ組成の例8) 
に，その適用は低りん低硫の高価な鉱石に限られた，表 2 にみるように，パドル法とベッセマー法のスラグ組成 が大幅に異なることが注目され，べッセマー法では， $\mathrm{P}_{2} \mathrm{O}_{5}$ を容易には生成し得ないことが理解された，スラ グ中の $\mathrm{FeO}$ を高めるために, 溶融 $\mathrm{FeO}$ をあらかじめ 装入して行つた吹鍊法は, 強力なスロッピングと炉壁侵 食により放棄せざるを得なかつた，パドル法の条件に近 づけるための残された方法は低温にすることであり，溶 銑を鉄鉱石を主体に，石灰あるいは Mn 鉱石を加えた 裏張りの回転炉 (ペルノー炉) 等で䚌找処理を行うこと により，互を $3 \%$ 台に維持しつつ，Pを $0.1 \%$ 前後に 下げることができた。

$\mathrm{FeO}$ が塩基の主役であり得た理由は，それが鉄鉱石 あるいは製品鉄よりも大量に副生したシンダー（高 $\mathrm{FeO}$ スラグ）の形で常に手元にあつたことと低温処理が考兄 られる．溶鉱炉操業の経験により， $\mathrm{CaO}$ が $\mathrm{FeO}$ より も高温で安定な塩基であることは知られていたが, 高炉 スラグが $\mathrm{P}_{2} \mathrm{O}_{5}$ を固定し得ていなかつたために, 脱り ん力は評価されていなかつた。 パドル法で脱硫を目的 に $\mathrm{CaO}$ 添加の試みがあつたが，製品鉄中に混入して 鍛造加工時の破断の 原因となることがしばしば 経験さ れ，パドル法での $\mathrm{CaO}$ 添加はむしろ有害と評価され ていた4).

しかし，ベッセマー転炬で脱りんを行うには炉内に塩 基を確保する必要があり, 炬壁侵食を防止する観点から は高温でより安定な塩基である $\mathrm{CaO}$ を使用すべきこ とは, ベッセマー転炉の開発当初から指摘されてはい た4). 1872 年に SNELUS は $\mathrm{CaO}$ 裏張りした小形炉で吹 錬実験に成功し, その際, 脱りんが予想以上に進行して いるのを見出した ${ }^{8)}$. この結果は最終的にトーマス法の 成功に結実し, これ以降, $\mathrm{CaO}$ が塩基の主役を占める こととなつた.

20 世紀に入ると合金系ばかりでなく，スラグ系でも 状態図の研究が盛んに行われ, 急速にデータの蓄積が進 む. スラグ系の融点と組成の関係を記述するには, 珪酸 度の概念が便利だつたようで，1926 年の大石のスラグ に関する解説でも盛んに珠酸度を用いている99.

これに対して，SCHENCK の著書では, 1930 年前後に 種々の形での塩基の提案があつたことを紹介しており， 脱硫や脱りんなどの化学的作用を表すには, 塩基度の概 念の方が有効という認識の変化をらかがわせる. そし て, 塩基度として過剩塩基や遊離石灰の概念を用いるこ とが大石を含め何人かで提案され，(3)式のような脱り ん反応平衡式が得られている． $\mathrm{CaO}$ を主体とする塩基 性スラグでは，この表示の有効性が広く認められた。

CHIPMAN らによる脱硫平衡の 過剩塩基を用いた記述や 脱りん平衡に関する考察はその最も典型的な仕事となつ $た^{10111)}$.

\section{2 活量係数}

19 世紀の後半に Henry の法則や Raoult の法則が見 出され，20 世紀初頭には, GIBBS により理想溶液に関す る理論は集大成された. 1923 年に LEWIS と RANDALL ${ }^{12)}$ は活量の概念を導入し, 理想溶液からの偏倚を示す溶液 の取り扱いを可能とし, 溶液論の世界が拡大された.

活量の鉄冶金への導入は若干遅れ，たと党ば，(3)式 にみられるように, SCHENCK の著書にも適用されてはい ないが，それは同書でも断わつているように，活量係数 の実測值の蓄積が無かつたためである. その後, 1934 年

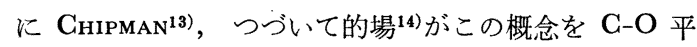
衡に適用し，1936 年には佐野 ${ }^{15}$ による解説が試みられ るに至つている. その後は溶融スラグも含め活量測定は 広範に行われ，1952 年 WAGNER により多成分希薄溶液 に打ける活量係数に関する極めて見通しの良い理論にま とめあげられた ${ }^{16}$ 。 この後の溶液論の発展には萬谷 ${ }^{17)}$ 詳しい解説がある.

\section{$2 \cdot 3$ スラグのイオン論}

X線（1895）とX線による回折現象（1912）の発見以 後, 固体結晶の構造解析の実験が広く行われ, 1932 年 には BRAGG による珪酸塩などの構造に関する著書が出 版される程に ${ }^{18)}$ 知識の蓄積が進んだ. これと平行して, LEWIS の原子価理論（1916）を足場に，化学結合の理論 が進展し珪酸塩におけるイオン結合と共有結合の特徵の 理解も深められた。これらはPAULING により集大成さ れた

このような成果を基礎に, HERASYMENKo は20), 溶融 スラグについて構成酸化物がイオン解離していることを 前提にしたイオン溶液モデルを提案（1938）し，脱硫反 応の解釈に有用であることを示した。

Lux ${ }^{21)}$ は酸塩基反応を次のように表し，

$$
\text { 塩基 }=\text { 酸 }+\mathrm{O}^{2-}
$$

$\mathrm{O}^{2-}$ の供与体を塩基, 受容体をそれに共役な酸と定義 した.こうして， $\mathrm{O}^{2-}$ の活量は塩基度と結び付くこと で, スラグの性質を把握する上での重要な概念となつ た、さらに，DIETZEL 22) がイオン結晶に扑けるクーロン 場の強さの尺度として酸素イオンとの引力を表す指数を 導入し, それが球酸塩溶液の挙動や塩基度の解釈に適用 されるに和よび，スラグ構造の面からも $\mathrm{O}^{2-}$ のイメー ジは明確にされた。

\section{4 キャパシティ}

スラグ中の $\mathrm{S}$ としての溶解度や活量は個々の硫化物の 溶解度や活量では表現できない. (1)，(2)式のような 組み合わせを考学てもそれが正しいといら保証は得られ ない。

そこで, RighaRdSON らは, (S) としての溶解反応 を次式のように考兄た ${ }^{23)}$.

$$
1 / 2 \mathrm{~S}_{2}+\mathrm{O}^{2-}=\mathrm{S}^{2-}+1 / 2 \mathrm{O}_{2}
$$

ここで, この式の平衡定数を $K_{7}$ とすると

$$
K_{7}=a_{\mathrm{S}^{2}}-P_{\mathrm{O}_{2}}{ }^{1 / 2} / a_{\mathrm{O}^{2}}-P_{\mathrm{S}_{2}}{ }^{1 / 2}
$$




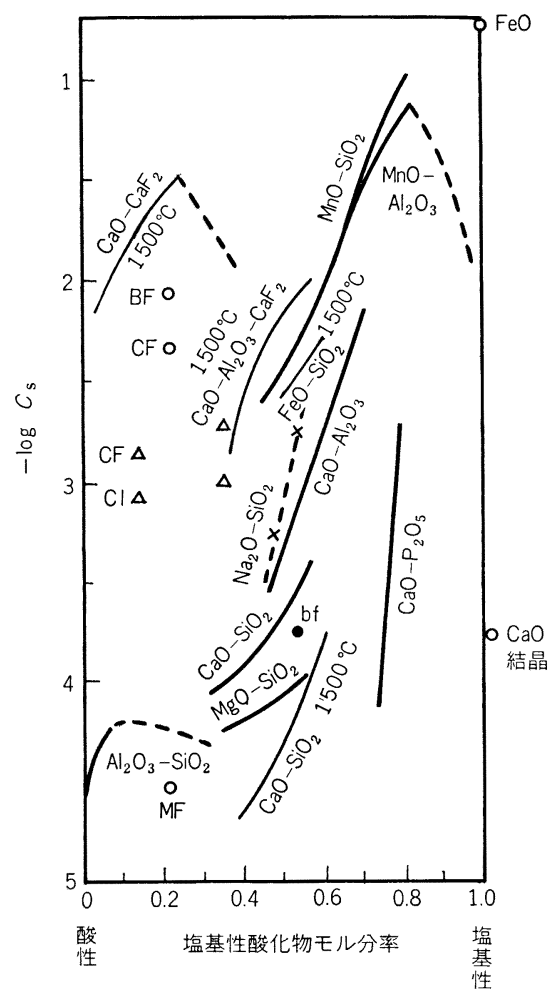

太線仙 $1650^{\circ} \mathrm{C}$, 紐線, bf $1500^{\circ} \mathrm{C}^{24)}, \mathrm{Na}_{2} \mathrm{O}-\mathrm{SiO}_{2}\left(1350^{\circ} \mathrm{C}\right)^{26)}$, 他は $\mathrm{CaO}$ と $\mathrm{BF}\left(\mathrm{BaF}_{2}\right), \mathrm{CF}\left(\mathrm{CaF}_{2}\right), \mathrm{MF}\left(\mathrm{MgF}_{2}\right), \mathrm{Cl}\left(\mathrm{CaCl}_{2}\right)$ との 各二元系 ${ }^{25)-b)}, \bigcirc 1400^{\circ} \mathrm{C}, \triangle 1350^{\circ} \mathrm{C}$

図 1 各種スラグのサルファイド・キャパシティ

$$
=f_{\mathrm{S}^{2-}}\left(\% \mathrm{~S}^{2-}\right) P_{\mathrm{O}_{2}}{ }^{1 / 2} / a_{\mathrm{O}^{2}-} P_{\mathrm{S}_{2}}{ }^{1 / 2}
$$

$f_{\mathrm{S}}{ }^{2-}$ は $(\% \mathrm{~S})$ についての Henry 基準の活量係数であ る. 今, 次式により $C_{\mathrm{S}^{2-}}$ を定義する.

$$
C_{\mathrm{S}^{2}}\left(=\mathrm{K}_{7} a_{\mathrm{O}^{2-}} / f_{\mathrm{S}^{2-}}\right) \equiv\left(\% \mathrm{~S}^{2-}\right) P_{\mathrm{S}_{2}}{ }^{1 / 2} / P_{\mathrm{O}_{2}}{ }^{1 / 2} \cdots(9)
$$

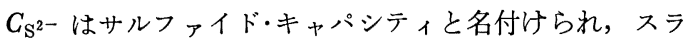
グの $\mathrm{S}^{2-}$ としての溶解能力を与える量として, 第 3 項 の関係を用いて実測できる. 物理的内容は（）内の第 2 項により理解することができる.すなわち，（7)式の 平衡定数と酸素イオン活量に比例し, $\mathrm{S}^{2-}$ イオンの活量 係数に反比例している.

$C_{\mathrm{S}}{ }^{2-}$ は RICHARDSON ら以後, 多くの系で測定されて いる. 図 1 に彼らの結果を中心に示した 24) 26).

スラグと接する気相の酸素分圧が高い場合には, S は 次式のように酸化体で溶解すると考えられる.

$$
1 / 2 \mathrm{~S}_{2}+3 / 2 \mathrm{O}_{2}+\mathrm{O}^{2-}=\mathrm{SO}_{4}^{2-}
$$

この時,

$$
\begin{aligned}
C_{\mathrm{SO}_{4}{ }^{2-}} & \left(=K_{10} a_{\mathrm{O}^{2-}} / f_{\mathrm{SO}_{4}{ }^{2-}}\right) \\
& \equiv\left(\% \mathrm{SO}_{4}^{2-}\right) / P_{\mathrm{S}_{2}}{ }^{1 / 2} P_{\mathrm{O}_{2}}{ }^{1 / 2}
\end{aligned}
$$

$C_{\mathrm{SO}_{4}{ }^{2-}}$ はサルフェイト・キャパシティである.

このように, キャパシティはその中に酸素イオン濃度 すなわち塩基度の寄与を含むために, 塩基度の尺度とな

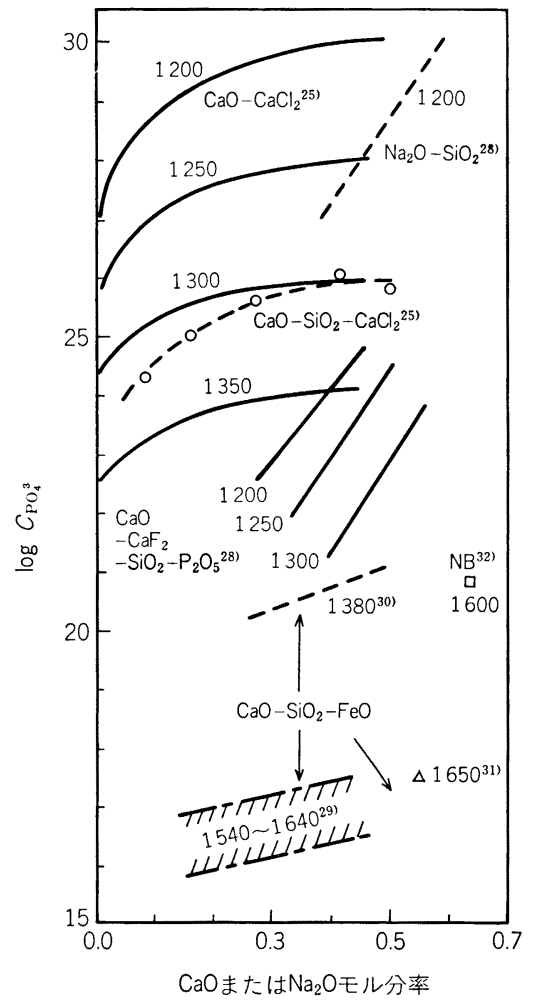

$\mathrm{CaO}-\mathrm{SiO}_{2}-\mathrm{CaCl}_{2}$ 系 $\left(\mathrm{CaO} / \mathrm{SiO}_{2}=3 \sim 4\right), \mathrm{CaO}-\mathrm{CaF}_{2}-$ $15 \% \mathrm{SiO}_{2}-5 \% \mathrm{P}_{2} \mathrm{O}_{5}, \mathrm{NB}: \mathrm{CaO}-\mathrm{CaF}_{2}-\mathrm{Na}_{2} \mathrm{~B}_{4} \mathrm{O}_{7}$ 禾

因 2 各種スラグのフォスフェート・キャパシティ

る可能性をもつている．かかる見地から，C. WAGNER はキャパシティの概念を後述のように拡張して, 塩基度 の尺度の測定法を提案した ${ }^{27)}$. その中で，WAGNERはフ ォスフェート・キャパシティを次式で定義している.

$$
\begin{aligned}
1 / 2 \mathrm{P}_{2} & +5 / 4 \mathrm{O}_{2}+3 / 2 \mathrm{O}^{2-}=\mathrm{PO}_{4}^{3-} . \\
C_{\mathrm{PO}_{4}{ }^{3-}} & \left.=K_{12} a_{\mathrm{O}^{2-}} / f_{\mathrm{PO}_{4}{ }^{3-}}\right) \\
& \equiv\left(\% \mathrm{PO}_{4}^{3-}\right) / P_{\mathrm{O}_{2}}{ }^{5 / 4} P_{\mathrm{P}_{2}}{ }^{1 / 2}
\end{aligned}
$$

これらの式と以下の式を組み合わせれば，

$$
\begin{aligned}
& 1 / 2 \mathrm{P}_{2}=\underline{\mathrm{P}} \\
& K_{\mathrm{P}}=f_{\mathrm{P}}[\% \mathrm{P}] / P_{\mathrm{P}_{2}}{ }^{1 / 2} \\
& \mathrm{P}+5 / 4 \mathrm{O}_{2}+3 / 2 \mathrm{O}^{2-}=\mathrm{PO}_{4}^{3-} \\
& C^{\prime}{ }_{\mathrm{PO}_{4}{ }^{3-}} \equiv\left(\% \mathrm{PO}_{4}{ }^{3-}\right) / P_{\mathrm{O}_{2}}{ }^{5 / 4} f_{\mathrm{P}}[\% \mathrm{P}]
\end{aligned}
$$

スラグーメタル反応の平衡より $C^{\prime}$ を求め, フォスフェ ート・キャパシティが計算できる. 図 2 に, 各種の測定 值より算出した $C_{\mathrm{PO}_{4}{ }^{3-}}$ の值を総括した ${ }^{25) 28) ~ 32)}$.

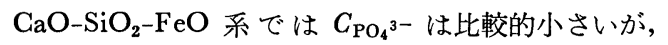
$\mathrm{SiO}_{2}$ を $\mathrm{CaF}_{2}$ や $\mathrm{CaCl}_{2}$ で置き換えた系の $C_{\mathrm{PO}_{4}{ }^{3-} \text { は極 }}$ めて大きいこと，ならびにそれらの温度依存性も非常に 大きいことが特徵的である.

$$
\begin{aligned}
& \text { このよらなキャパシティの概念は他にも，たとえば， } \\
& \mathrm{C}+\underline{\mathrm{N}}+1 / 2 \mathrm{O}^{2-}=\mathrm{CN}-+1 / 4 \mathrm{O}_{2} \\
& \mathrm{Cr}+3 / 4 \mathrm{O}_{2}+3 / 2 \mathrm{O}^{2-}=\mathrm{CrO}_{3}^{3-}
\end{aligned}
$$




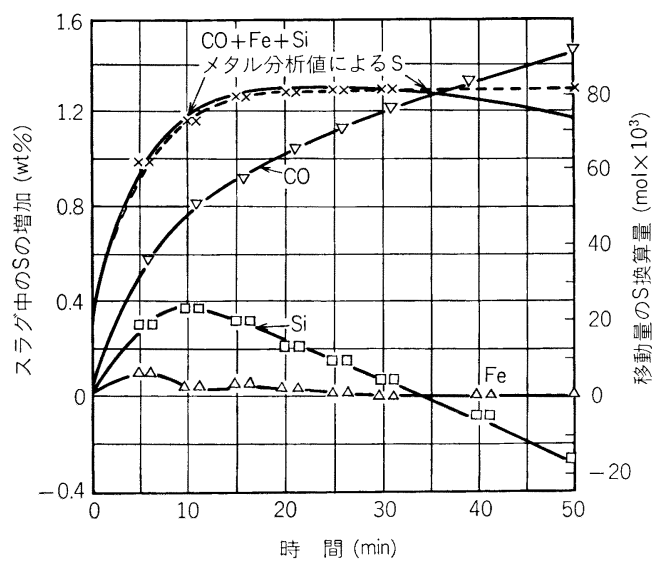

Run $K$, 温度 $1505^{\circ} \mathrm{C}$, スラグ $48 \% \mathrm{CaO}, 21 \% \mathrm{Al}_{2} \mathrm{O}_{3}$ ， $31 \% \mathrm{SiO}_{2}$, 初期 $[\mathrm{Si}] 0.16 \%$, 平衡 $[\mathrm{Si}] 0.5 \%$

図 3 メタルからスラグへ移動した $\mathrm{S} ， \mathrm{Fe}$ および $\mathrm{Si}$ と発生した $\mathrm{CO}$ の $\mathrm{S}$ 換算モル量5)

などの式により，サイアナイドあるいはクロメイト・キ ャパシティなどに拡張することがでさる.

このよらなキャパシティの概念を用いることについて はサルファイドやナイトライドのようなアニオンの溶解 度を与えるという点で前述のような利点を認めることが でさる，しかし，たとえば Pや Cr などカチオンになる ものについては，それらの酸化物の活量を使うことに対 して，どのような利点があるか議論の余地があろう。た とえば，水渡らは， $\mathrm{CaO}-\mathrm{MgO}-\mathrm{SiO}_{2}-\mathrm{FeO}-\mathrm{Fe}_{2} \mathrm{O}_{3}$ 系ス ラグ中の $\mathrm{P}_{2} \mathrm{O}_{5}$ の活量係数を, 次のように求めている ${ }^{31)}$.

$$
\begin{aligned}
2 \underline{\mathrm{P}}+5 \mathrm{O} & =\mathrm{P}_{2} \mathrm{O}_{5}(1) \cdots \cdots \cdots \cdots \cdots \cdots \cdots \cdots \cdots \cdots(20) \\
\log \gamma_{\mathrm{P}_{2} \mathrm{O}_{5}} & =-26300 / T+11.2 \\
& -1.01\left(23 N_{\mathrm{CaO}}+17 N_{\mathrm{MgO}}+8 N_{\mathrm{FeO}}\right) \cdots(21)
\end{aligned}
$$

これらの式に(13)，(17)の定義式と(15)式を組み合わせ ると, フォスフェート・キャパシティが求められる.

$\log C_{\mathrm{PO}_{4}{ }^{3-}}=53200 / T-18.56+11.6 N_{\mathrm{CaO}}+8.6 N_{\mathrm{MgO}}$

$$
+4.0 N_{\mathrm{FeO}}
$$

したがつて (21)，(22)の比較では，とくにキャパシティ を採用すべき大きな利点はない，しかし， $\mathrm{CaF}_{2}$ や $\mathrm{CaCl}_{2}$ あるいはほう酸塩など特殊なアニオンを含む系で も，見通しの良い比較を与えてくれる上に，後述 $(3 \cdot 1 \cdot 3)$ するように，キャパシティのデータの蓄積は， 塩基度に関する普遍的な尺度を提供する可能性も持つて いる。

\section{5 電気化学的概念}

スラグのイオン構造論を基礎に，スラグの電導度や輸 率など電気化学的測定法の適用が，スラグの構造解明に 寄与した。ささらに進んで，スラグーメタル反応を電気化 学的に解釈することにより，スラグーメタル反応の多元 反応としての特徵の理解が深められた。

たと亲ば，溶銑の脱硫反応は b)

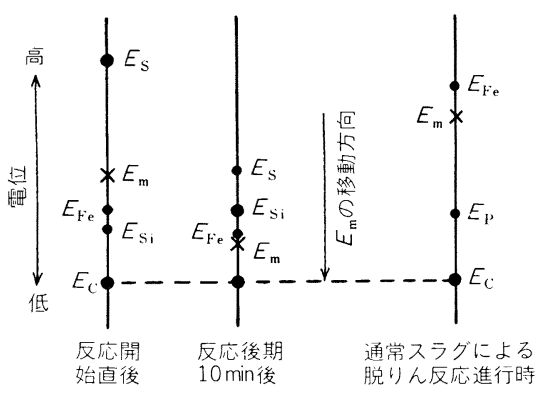

図 4 脱硫 ( $\mathrm{a}, \mathrm{b})$ および脱りえ（c）反応進行時 の界面に打河各電位の位置関係模式図

$\mathrm{S}+\underline{\mathrm{C}}+\mathrm{CaO} \rightarrow \mathrm{CaS}+\mathrm{CO}$

のように記述される。ころが，KING ら ${ }^{33)}$ は高硫黄の $\mathrm{Fe}-\mathrm{C}-\mathrm{Si}$ 融体とスラグを接触させた時, 図 3 のような 反応経過を見出した. すなわち, 初期の急速な脱硫反応 に伴つて，本来還元されるはずの $\mathrm{Si}$ とさらに $\mathrm{Fe}$ が酸 化を受け，その後，脱硫反応速度の鈍化につれ， $\mathrm{Si}$ と $\mathrm{Fe}$ は再び還元されている.

それらの成分の動きは次のような酸化還元反応の組み 合わせで進行すると解釈された.

カソード反応 (還元反応) アノード反応（酸化反応） 初期 :

$\underline{\mathrm{S}}+2 e \rightarrow \mathrm{S}^{2-}$

$$
\begin{aligned}
& \mathrm{Fe} \rightarrow \mathrm{Fe}^{2+}+2 e \\
& \mathrm{Si} \rightarrow \mathrm{Si}^{4+}+4 e \quad \cdots \cdots \cdots \\
& \mathrm{C}+\mathrm{O}^{2-} \rightarrow \mathrm{CO}+2 e
\end{aligned}
$$

後期 :

$$
\begin{aligned}
& \mathrm{S}+2 e \rightarrow \mathrm{S}^{2-} \quad \mathrm{C}+\mathrm{O}^{2-} \rightarrow \mathrm{CO}+2 e \\
& \mathrm{Fe}^{2+}+2 e \rightarrow \mathrm{Fe} \\
& \mathrm{Si}^{4+}+4 e \rightarrow \mathrm{Si}
\end{aligned}
$$

各単位反応について，次のような単極電位 $E_{\mathrm{i}}$ が与兄 られる。

$$
\begin{aligned}
& E_{\mathrm{i}}=E_{\mathrm{i}} \mathrm{o}+(R T / \mathrm{z} F) \cdot \ln [\mathrm{Oxd}]_{\mathrm{i}} /[\mathrm{Red}]_{\mathrm{i}} \\
& E_{\mathrm{i}} \mathrm{o}=\Delta G_{\mathrm{i}} \mathrm{o} / \mathrm{z} F \quad \ldots \ldots \ldots \ldots \ldots \ldots \ldots \ldots \ldots \ldots \ldots \ldots \ldots \ldots \ldots \ldots \ldots \ldots
\end{aligned}
$$

$E_{\mathrm{i}}{ }^{\circ}$ は標準電位で $(29)$ 式により標準自由エネルギー変 化と結びつけられる。 $z$ は荷電数, $F$ はファラデー定数, $[\mathrm{Oxd}]_{\mathrm{i}}$ および $[\mathrm{Red}]_{\mathrm{i}}$ はおのおの $\mathrm{i}$ 成分の酸化体 $(\mathrm{S}$, $\left.\mathrm{Fe}^{2+}, \mathrm{SiO}_{4}^{4-} な と ゙\right)$ の活量積および還元体 ( $\mathrm{S}^{2-}, \mathrm{Fe}$, $\mathrm{Si} ＼textrm{O}^{2}$-など）の活量積である.

酸化体の濃度が高ければその反応の電位は高く，より 低い電位の反応と組み合わせれば，カソード反応を進行 させて, 酸化体の濃度を減ずる. 非平衡状態にある界面 で注目する反応がカソードもしくはアノードのどちらの 方向へ進行するかは，その反応の電位 $E_{\mathrm{i}}$ と反応系の 実際の電位 $E_{\mathrm{m}}$ との関係で決まる. 電気化学の世界では $E_{\mathrm{m}}$ は混成電位あるいは腐食電位と呼ばれる。

$$
\eta_{\mathrm{i}}=E_{\mathrm{m}}-E_{\mathrm{i}}<0 \text { ならばカソード反応, } \eta_{\mathrm{i}}=E_{\mathrm{m}}-E_{\mathrm{i}}>0
$$




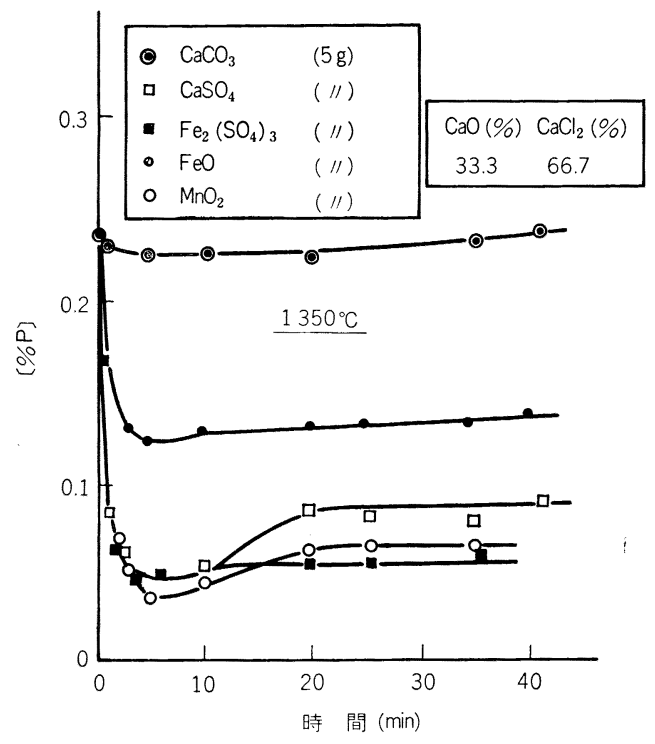

図 5 各種酸化剂による脱りえ挙動

ならばアノード反応として進行し， $\eta_{\mathrm{i}}=E_{\mathrm{m}}-E_{\mathrm{i}}=0$ の 時は見掛け上反応は停止しているが， $E_{\mathrm{m}}$ の変化に追随 $し て, E_{\mathrm{i}}$, つまり濃度比が 調節される, いわば部分平 衡 の状態にある. 図 3 に対する $E_{\mathrm{m}}$ と各 $E_{\mathrm{i}}$ の位置関 係を模式的に示すと図 4 のようになる36)37).

反応初期は $a_{\underline{\mathrm{S}}} / a_{\mathrm{S}}{ }^{2-}$ が極めて大きいため $E_{\mathrm{S}}$ が高く, それに伴つて $E_{\mathrm{m}}$ が $E_{\mathrm{Si}}$ や $E_{\mathrm{Fe}}$ よりも高くなるため, (25 a ) や (26 a ) のごとく, Si や Fe が酸化される. 脱 硫が進行し $E_{\mathrm{S}}$ が低下寸ると $E_{\mathrm{m}}$ も下がり, カソード反 応として $(24) ，(25 \mathrm{~b}) ，(26$ b )が進行することになる. 通常の溶銑処理条件では, 図にみるように, $E_{\mathrm{c}}$ が圧倒 的に安定なために $E_{\mathrm{m}}$ は常に下向きへの变化を強いられ る. $E_{\mathrm{c}}$ が $E_{\mathrm{m}}$ に一致した時, 全平衡状態34)が達成され たことになる.

次式のように表される脱りん反応を進めるには, 図 4 cのよらに,

$$
\mathrm{P}+4 \mathrm{O}^{2-} \rightarrow \mathrm{PO}_{4}^{3-}+5 e
$$

$E_{\mathrm{m}}$ を $E_{\mathrm{p}}$ に対して高く維持すると同時に $E_{\mathrm{p}}$ 自身は酸 化体の活量を下げて低位に維持する必要がある． $E_{\mathrm{m}}$ を 高くするには, 次のよらなカソード反応と組み合わせる.

$$
\begin{aligned}
& \mathrm{O}+2 e \rightarrow \mathrm{O}^{2}-\cdots \cdots(3 \mathrm{l}) \quad 1 / 2 \mathrm{O}_{2}+2 e \rightarrow \mathrm{O}^{2}-\cdots \\
& \mathrm{Fe}^{2+}+2 e \rightarrow \mathrm{Fe} \cdots \cdots(25 \mathrm{~b}) \quad \mathrm{Fe}^{3}+3 e \rightarrow \mathrm{Fe} \cdot \cdots
\end{aligned}
$$

次のようなカソード反応も考えられる.

$$
\begin{aligned}
& \mathrm{CO}_{3}^{2-}+4 e \rightarrow \mathrm{C}+3 \mathrm{O}^{2-} . \\
& \mathrm{CO}_{3}^{2-}+2 e \rightarrow \mathrm{CO}+2 \mathrm{O}^{2-} \\
& \mathrm{SO}_{4}^{2-}+8 e \rightarrow \mathrm{S}^{2-} 4 \mathrm{O}^{2-} \\
& \mathrm{SO}_{4}^{2-}+6 e \rightarrow \underline{\mathrm{S}}+4 \mathrm{O}^{2-} .
\end{aligned}
$$

†移動平衡という表現もあるが，とてでは $\mathrm{KOCH}^{34) や T U R K D O G A N ~}{ }^{35)}$ の表現にならう。
$\mathrm{SO}_{4}^{2-}+2 e \rightarrow \mathrm{SO}_{2}+2 \mathrm{O}^{2-}$

炭酸塩や硫酸塩を用いる場合，(34)や(36)の反応を利 用できれば効率は高いが，(35)や(38)のように直接ガス 発生を伴らような反応条件では効率が悪くなる。図 5 に，このよらな反応による脱りんの例を示した ${ }^{38)}$. (37) が進行すれば著しい加硫が伴うはずであるが，図の結果 では溶鉄中の S の上昇は認められず，(36)により脱りん が進行していると考觉られる.

さらに，目的に応じては，次のような反応の利用も考 它られる。

$$
\begin{aligned}
& \mathrm{Cr}_{2} \mathrm{O}_{5}^{4-}+6 e \rightarrow 2 \underline{\mathrm{Cr}}+5 \mathrm{O}^{2-} \\
& \mathrm{MnO}_{4}^{-}+7 e \rightarrow \underline{\mathrm{Mn}}+4 \mathrm{O}^{2-}
\end{aligned}
$$

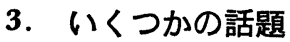

\section{1 塩基度の評価法}

塩基度はスラグの基本的な物性であり，その評価は実 用的にも重要なため, 測定法あるいは表示法については 古くから多数の提案がある.

$\mathrm{CaO} / \mathrm{SiO}_{2}$ 比や過剰塩基の概念は先に述べた. ここで は, 各種の評価法について概観する.なお塩基度の化学 的基礎については横川の極めて要を得た解説 ${ }^{39)}$ があり, 他に電気化学における総説に詳しい40).

$3 \cdot 1 \cdot 1$ 電気化学的方法

塩基度は酸素イオン活量 $a_{\mathrm{o}}{ }^{2-}$ で表示できる.

DidTsahenko ら 41) $^{4}$ 次のような液間接続を有する電 池を組んで珪酸スラグ中の相対的な $a_{\mathrm{O}}{ }^{2-}$ の測定を試み た。

$$
\mathrm{Pt} \text { ( I ) : } \mathrm{O}_{2} \mid \text { スラグ I ||スラグ II } \mid \mathrm{O}_{2}: \mathrm{Pt}(\mathrm{II})
$$

しかし，イオンの活量自身を直接熱力学的量として測 定することはできない. (41)で測定される起電力 $E_{41}$ は たとえば，両スラグ相に拈ける $\mathrm{Ca}^{2+}$ の輸率が 1 である 場合に

$$
E_{41}=(R T / z F) \cdot \ln \left(P_{\mathrm{O}_{2}}\right) \text { II } /\left(P_{\mathrm{O}_{2}}\right) \mathrm{I} \cdot a_{\mathrm{CaO}} \mathrm{I} / a_{\mathrm{CaO}} \mathrm{II}
$$

したがつて, $P_{\mathrm{O}_{2}} \mathrm{I}=P_{\mathrm{O}_{2}}$ III でかつ, $a_{\mathrm{Ca}^{2+}} \mathrm{I}=a_{\mathrm{Ca}}{ }^{2+} \mathrm{II}$ と いら仮定が成立する時にのみ,

$$
E_{41}=-R T / z F \ln a_{\mathrm{O}^{2-}} \mathrm{II} / a_{\mathrm{O}^{2-}} \mathrm{I}
$$

となり, 起電力を酸素イオンの相対活量を与光るものと みなすことができる42).

このような電気化学的測定による $a_{\mathrm{O}^{2-}}$ 比の決定は酸 化物以外の溶媒では有用な結果を与えているが，スラグ 系では推奖されてはいない27).

\section{$3 \cdot 1 \cdot 2$ 森の提案}

森は酸化鉄を含むスラグでは， $\mathrm{Fe}^{3+} / \Sigma \mathrm{Fe}$ の比がス ラグの塩基度によつて顕著に変わるといらよく知られた 事実に基づき，この比の変化を塩基度の尺度に用いるこ とを考えた ${ }^{43)}$. すなわち， $r$ を $\mathrm{Fe}$ イオンの比， $C$ を陽 イオンのみを考えたイオン分率として 


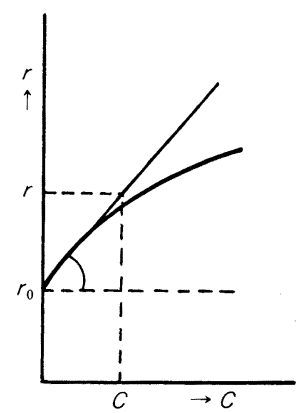

図 $6 \quad r$ と $C$ の関係図 ${ }^{43}$

$r=\mathrm{Fe}^{3+} /\left(\mathrm{Fe}^{2+}+\mathrm{Fe}^{3+}\right)=\mathrm{Fe}^{3+} / \Sigma \mathrm{Fe}$

$C=\Sigma \mathrm{M} /(\Sigma \mathrm{Fe}+\Sigma \mathrm{M})$

ただし， $\Sigma \mathrm{M}=\mathrm{Ca}^{2+}+\mathrm{Si}^{4+}+\mathrm{Al}^{3+}+\cdots \quad \cdots(46)$

とすると, $r$ は $C$ の関数として, 図6のような曲線を 描く. 故に $C \rightarrow 0$ での接線を求めると, その勾配は $C$ に よらず一定となるはずである．実験的には $P_{\mathrm{O}_{2}}$ を一定 にして $\mathrm{FeO}$ 融液に目的のスラグを少量ずつ添加し $C$ が 小さく $r$ の変化が直線的な範囲で

$(d r / d C)_{\mathrm{C} \rightarrow \mathrm{O}}=r-r_{0} / C=\mathrm{B}^{\prime}$ による塩基度 $\mathrm{B}^{\prime}$ が得られ る.

森は $\mathrm{CaO}-\mathrm{SiO}_{2}$ を中心にこれに $\mathrm{TiO}_{2}, \mathrm{Al}_{2} \mathrm{O}_{3}$ の入 つた系で $\mathrm{B}^{\prime}$ を求め, 実験式を得ている.

ここで得られた塩基度が酸素イオン活量 $a_{\mathrm{O}}{ }^{2-}$ とどの ように関係しているかを考えてみる，通常のスラグ中で は $\mathrm{Fe}^{3+}$ は $\mathrm{O}^{2}$ - を配位しているとみなされるが，その 配位状態はスラグの塩基度や共存イオン種によつて変わ るので, $\mathrm{Fe}^{2+}$ と $\mathrm{Fe}^{3+}$ の反応を次のように考える.

$\mathrm{Fe}^{2+}+1 / 4 \mathrm{O}_{2}+n / 2 \mathrm{O}^{2-}=\mathrm{FeO}_{(\mathrm{n}+1) / 2}{ }^{2-\mathrm{n}}(n=1,2,3)$

この時

$$
\begin{aligned}
& K_{47}=a_{\mathrm{FeO}(\mathrm{n}+1) / 2}{ }^{2-\mathrm{n}} / a \mathrm{Fe}^{2+} P_{\mathrm{O}_{2}}{ }^{1 / 4}\left(a_{\mathrm{O}^{2-}}\right)^{\mathrm{n} / 2} \cdots \\
& X_{\mathrm{FeO}(\mathrm{n}+1) / 2}{ }^{2-\mathrm{n}} / X_{\mathrm{Fe}^{2+}}=K_{47} P_{\mathrm{O}_{2}}{ }^{1 / 4}\left(a_{\mathrm{O}^{2-}}\right)^{\mathrm{n} / 2} \rho
\end{aligned}
$$

ただし， $\rho=\gamma_{\mathrm{Fe}^{2+}} / f_{\mathrm{FeO}(\mathrm{n}+1) / 2^{2-\mathrm{n}}}$ は，活量係数の比で $X_{\mathrm{Fe}^{2+} \rightarrow 1}$ の時 $\gamma \rightarrow 1, X_{\mathrm{FeO}(\mathrm{n}+1) / 2^{2-\mathrm{n}} \rightarrow 0}$ で $f \rightarrow 1$ であ る.

今, 式の単純化のために $\mathrm{Fe}^{2+}>>\mathrm{Fe}^{3+}$ となるよう に $P_{\mathrm{O}_{2}}$ を十分に小さくとれば,

$$
r=\mathrm{Fe}^{3+} / \Sigma \mathrm{Fe} \sim \mathrm{Fe}^{3+} / \mathrm{Fe}^{2+}=K_{47} P_{\mathrm{O}_{2}}{ }^{1 / 4}\left(a_{\mathrm{O}^{2-}}\right)^{\mathrm{n} / 2} \rho
$$

故に

$$
\begin{aligned}
\mathrm{B}^{\prime}= & r-r_{0} / C=K_{47} P_{\mathrm{O}_{2}}{ }^{1 / 4}\left[\left(a_{\mathrm{O}^{2-}}\right)^{\mathrm{n} / 2} \rho\right. \\
& \left.-\left(\left(a_{\mathrm{O}^{2-}}\right)^{\mathrm{n} / 2} \rho\right)_{0}\right](\Sigma \mathrm{Fe}+\Sigma \mathrm{M}) / \Sigma \mathrm{M} \cdots(51)
\end{aligned}
$$

ここに, $\left(\left(a_{\mathrm{O}}{ }^{2-}\right)^{\mathrm{n} / 2} \rho\right)_{0}$ は添加スラグ量=0 の時の $a_{\mathrm{O}}{ }^{2-}, \rho$ 扎よび $n$ であることを示す. スラグの添加は これら 3 つの量の全てに一定の変化を引き起こす. $n$ と $\rho$ は酸化鉄融体に固有の因子であるから， $C \rightarrow 0$ の時に $a_{\mathrm{o}}{ }^{2-}$ のみが大きな変化を 起こすという保証が得られる 時に限り $\mathrm{B}^{\prime}$ は普遍的な塩基度の尺度となり得る.

森は鉄イオンを指示イオンに用いたが，価数のかわる 遷移金属イオンはいずれも同様な意味での指示イオンに なり得る. 任意のスラグ中に微量の指示イオンを加え, その比を塩基度と結びつけることは可能であるが，その 場合でも(47)式に拈ける $n$ に相当する数值の評価は残る ことになろら.

\section{$3 \cdot 1 \cdot 3$ WAGNER の提案}

WAGNER は塩基度の 定量的尺度として, 実測可能な 量について検討し，カーボネイト・キャパシティを塩基 度の定量的表現とすることを提案した ${ }^{27}$.

$$
B_{\mathrm{carb}}=C_{\mathrm{CO}_{3}{ }^{2-}} / C_{\mathrm{CO}_{3}{ }^{2-}}{ }^{*}
$$

ここに, $C_{\mathrm{CO}_{3}}{ }^{2-*}$ は基準スラグのカーボネイト・キャパシ ティである.

任意のスラグについて, $\mathrm{CO}_{2}$ の吸収反応を考えると

$$
\mathrm{CO}_{2}+\mathrm{O}^{2-}=\mathrm{CO}_{3}^{2-}
$$

$K_{53}=a_{\mathrm{CO}_{3}{ }^{2-}} / P_{\mathrm{CO}_{2}} a_{\mathrm{O}^{2-}}$

ここでカーボネイト・キャパシティを次式で定義する。

$$
C_{\mathrm{CO}_{3}{ }^{2-}} \equiv\left(\% \mathrm{CO}_{3}^{2-}\right) / P_{\mathrm{CO}_{2}}\left(=K_{53} a_{\mathrm{O}^{2-}} / f_{\mathrm{CO}_{3}{ }^{2-}}\right)
$$

$f_{\mathrm{CO}_{3}{ }^{2-}}$ は Henry 基準の值である.

(55)式の第 3 項に示したキャパシティの物理的内容か ら推論できるように，(52)が酸素イオンの相対活量に比 例した量を与えるには，基準スラグと対象とするスラグ

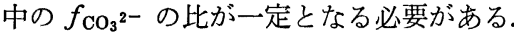

(52)式のような塩基度の定義は他のキャパシティ（た とえば $\left.B_{\mathrm{sulf}}=C_{\mathrm{S}^{2-}} / C_{\mathrm{S}^{2-}}{ }^{*}\right)$ を用いても可能であるが， WAGNER がとくに $\mathrm{C}_{\mathrm{CO}_{3}{ }^{2-}}$ を選んだ理由は, カーボネイ ト・イオがもつとも他のスラグ成分との 相互作用が弱

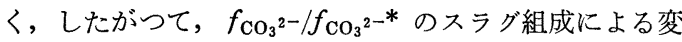
化が小さいと考皃たためである.

こうして, $C_{\mathrm{CO}_{3}{ }^{2}}{ }^{2}$ に関するデータが蓄積されれば，他 のキャパシティをたとえば

$$
C_{\mathrm{PO}_{4}{ }^{3-}}=C_{\mathrm{PO}_{4}{ }^{3-*}} \cdot B_{\mathrm{carb}^{3 / 2}}
$$

のように推定することが可能となる.

ただし，そのためには， $\left(C_{\mathrm{PO}_{4}{ }^{3-}}\right) /\left(C_{\mathrm{CO}_{3}{ }^{2-}}\right)^{3 / 2}$ がスラ グ組成に対して一定と打けるかどらかなどの実験的検証 が必要であり，このためにも，多くのスラグ系で各種の キャパシティ・データの蓄積が望まれる。

\section{$3 \cdot 1.4$ 鉄イオンの酸素配位数からの評価}

珪酸塩の構造解析によると塩基である $\mathrm{Fe}^{2+}$ や $\mathrm{Ca}^{2+}$ は $\mathrm{O}^{2-}$ が構成する 8 面体格子の 中心に位置し 6 個の $\mathrm{O}^{2-}$ を配位する. 一方 $\mathrm{Si}^{4+}$ は $\mathrm{O}^{2-}$ との結合が強く酸 素 4 面体格子の中心に位置し 4 個の $\mathrm{O}^{2-}$ を配位する. $\mathrm{Si}^{4+}$ と $\mathrm{O}^{2-}$ の距離はかなり近接して, 共有結合の性格 が強く $\mathrm{SiO}_{4}^{4-}$ として見える。

溶融状態でも基本的にはこのような構造が維持されて いると考えられる，溶融珪酸塩を急冷し，ガラス化した 
試料について, メスバウワー効果（ $\gamma$ 線吸収スペクト ル）を測定したところ， $\mathrm{Fe}^{3+}$ イオンのアイソマー・シ フトが溶媒の塩基度に対応して变化することが認められ た4445). 溶媒の塩基度が高く, $\mathrm{Fe}^{3+}$ と $\mathrm{O}^{2-}$ との結合 が相対的に強くなれば, その結果として 6 から 4 へと配 位数が変化すると推定された. 森永ら ${ }^{46)}$ は，このような 観点から各種の 2 元系珪酸塩に $\mathrm{Fe}_{2} \mathrm{O}_{3}$ を添加し, 空気 中で溶融後急冷したガラス化試料について，メスバウワ 一・スペクトルを測定し， $\mathrm{Fe}$ イオンの配位数について 考察した. その結果を要約すると，

1. $\mathrm{Fe}^{3+}$ のアイソマー・シフトは溶媒中のカチオン が $\mathrm{Ca}^{2+}, \mathrm{Li}^{+}, \mathrm{Sr}^{2+}, \mathrm{Ba}^{2+}, \mathrm{Na}^{+}, \mathrm{K}^{+}, \mathrm{Rb}^{+}$となる 順に小さくなり, $\mathrm{Fe}^{3+}$ と $\mathrm{O}^{2-}$ との共有結合性が強ま つてくる.

2. 塩基度の高くなる程 $\mathrm{Fe}^{2+}$ の吸収ピークは急激に 低下し, $\mathrm{Fe}^{3+}$ のピークが強くなる. LUPIS らの認めた ごとく45)アルカリ珪酸塩中では $\mathrm{Fe}^{2+}$ のピークはほとん どない.

3. $\mathrm{Fe}^{3+}$ は $\mathrm{SiO}_{2}$ 量の多い範囲では 8 面体位置を占 めるが, 塩基度の増加により，4配位 4 面体位置の存在 割合が増加する.

4. T. Fe イオンの増大は, $\mathrm{Fe}^{2+}, \mathrm{Fe}^{3+}$ (4 面体位 置) の低下をもたらし， $\mathrm{Fe}^{3+}$ (8 面体位置) が増大す る.

従来の測定はガラス化試料で金属酸化物 $\left(\mathrm{R}_{2} \mathrm{O}, \mathrm{RO}\right) /$ $\mathrm{SiO}_{2}$ 比は 1 までに限られているが, $\mathrm{Fe}_{2} \mathrm{O}_{3} /\left(\mathrm{RO}, \mathrm{R}_{2} \mathrm{O}\right)$ 比を一定にして, $\mathrm{Fe}^{3+}$ の酸素配位数を決定すれば塩基 度が評価できるといら点で今後のデータの蓄積により塩 基度評価法の 1 つとして利用し得ると期待される.

\section{$3 \cdot 1.5$ 光学的塩基度}

これまで, 塩基とは酸素イオンを放出しやすい酸化物 で塩基度とはそのように放出された $\mathrm{O}^{2-}$ の活量で表現 できるといら立場から，物理的に $a_{\mathrm{O}^{2-}}$ と対応するよう な表現形式を対象に評価法を検討してきた。応用面から いえば，それらの評価法が脱硫, 脱りん能などの実際的 なスラグの化学的性質を定量的に記述できれば，十分使 用に耐える. 逆に言えば，たとえ塩基度として理論的な 表現が完璧でも，スラグの化学的性質を記述する上で従 来の塩基度の概念と矛盾するようでは, 実用的には意味 が無いことになる。

この点から見ると， $a_{\mathrm{O}}{ }^{2-}$ で記述する塩基度は脱硫， 脱りんなどの化学反応の記述に当たつては十分な成果を 与えているが，その定量的尺度を与えるといら点では， それ自身が熱力学的測定対象になり得ないといら点で欠 陥を有している.

ところで，この $\mathrm{O}^{2-}$ の活量とは， $\mathrm{O}^{2}$ - の反応のしや すさを表し, 結合論的にみると, $\mathrm{O}^{2-}$ のもつている電子 対をどれだけ共有結合を作るために提供し得るかといら ことになる。このような電子対の供与を受けると, イオ

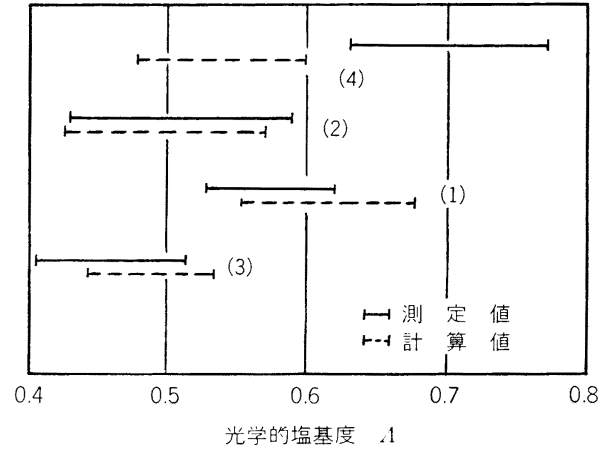

図 7 (1) 珪酸塩，(2) ほう酸塩，(3) りえ酸塩, (4) ゲルマニウム酸塩の各光学的塩基度の測定值 の範囲および計算値との比較

ンによつてはその中の電子のエネルギー準位が影響を受 け，その変化が吸収スペクトルに現れる.すなわら， 「塩基とは電子対供与体である」とした LEWIS の酸塩基 の定義にしたがう塩基度が直接分光学的に測定し得るこ とになる.

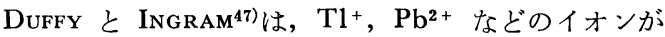
敏感に上述のような影響を受けることに着目し，これら のイオンを指示薬として対象とする酸化物溶液に加え, その紫外部の吸収スペクトルの位置からその溶液の塩基 度を決定する方法を提案し, 光学的塩基度 (Optical basicity) と名付けた．各構成イオンについての分光学的 測定值を集積することにより，溶液としての理想的塩基 度を求め得ることを示した，更に，このような電子状態 を反映する測定值は，たとえば Pauling の電子陰性度 とも明確に対応することを DUFFY らは指摘した.

実際に, $\mathrm{G}_{\text {ASKell }}{ }^{48)}$ は $\mathrm{CaO}-\mathrm{SiO}_{2}-\mathrm{Fe}_{\mathrm{t}} \mathrm{O}-\mathrm{MgO}$ 系スラ グの $\mathrm{P}$ 分配に関する実測データの解析に電子陰性度より 求めた光学的塩基度を適用し，その有用性を検討してい ๖.

これに対し, Sumita ら ${ }^{49)}$ は, 各種の 2 元酸化物溶液 のガラス化試料に対して, 光学的塩基度自身を実測し,

DUFFY らの方法による理論的塩基度の推定值と比較し た. 図7はそれを総括したもので，ほう酸塩系は実測值 に対して推定值とほぼ一致しているが，珪酸塩とりん酸 塩系では実際よりも塩基度を高目に推定し得ること，ゲ ルマニウム系では逆に実測值がはるかに高いことを示し ている. 塩基性酸化物の濃度はほぼ同様の範囲にあるの で, 図より，りん酸塩は珪酸塩よりはるかに酸性度の強 いことが明らかである。

この光学的塩基度は定量性の高いことで極めて魅力的 であるが，高温融体の直接測定が困難なこと，不透明あ るいは着色体には適用し難いことなど現状では制約が多 い. 精錬の分野で関心の高い高塩基側への拡張に対して も，新しい指示イオンや測定法など今後の開発が期待さ 


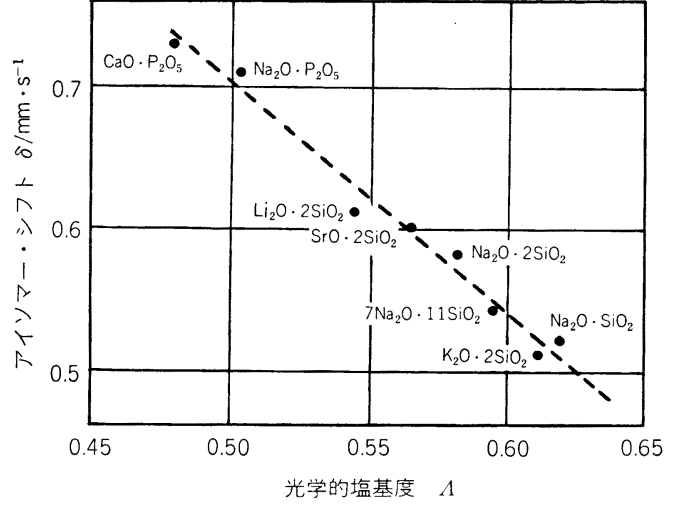

図 8 光学的塩基度とメスバウワー効果における $\mathrm{Fe}^{3+}$ のアイソマー・シフトとの関係

れるが，SUmita らは，不透明あるいは着色体への対策 としては，前節のメスバウワー効果の測定と関連付ける ことを提案している.

すなわち, 図 8 に示すごとく, $\mathrm{Fe}^{3+}$ のアイソマー・シ フトは光学的塩基度の実測值と良い直線性を持つてお り，このような関係を蓄積することで，塩基度の定量的 な評価をより普遍的に行いらることが期待される.

\section{2 界面酸素分圧}

2.5 で述べたように，スラグーメタル反応は電子を媒 介にして進行し，界面にお打る混成電位が各反応の進行 状態を支配している.この混成電位の把握が肝要で, そ のためには，2つの方向がある，1つは実測することで あるが，後述のようにスラグーメタル系では理論的，実 験的問題点が多く，実測例は乏しい，そこで，混成電位 を代替する便法を考学る50).

$3 \cdot 2 \cdot 1$ 界面酸素分圧の導入

2.5 のアノードおよびカソード反応の各式と次式を

$$
1 / 2 \mathrm{O}_{2}+2 e=\mathrm{O}^{2-}
$$

組み合わせれば，たとえば，

$$
\begin{aligned}
& \mathrm{P}+5 / 4 \mathrm{O}_{2}+3 / 2 \mathrm{O}^{2-}=\mathrm{PO}_{4}^{3-} \\
& \underline{\mathrm{Si}}+\mathrm{O}_{2}+2 \mathrm{O}_{2}=\mathrm{SiO}_{4}^{4-} \ldots \ldots . . .
\end{aligned}
$$

$\mathrm{Fe}+1 / 2 \mathrm{O}_{2}=\mathrm{FeO}$

などが得られる.ここで，各単位反応について，単極電 位に対応する酸素分圧を求めるために，(58)，(59)に対 しては次式を考劣る。

$$
\mathrm{P}+5 / 4 \mathrm{O}_{2}=\mathrm{PO}_{2.5}
$$

$\underline{\mathrm{Si}}+\mathrm{O}_{2}=\mathrm{SiO}_{2}$

電位の場合と同様に，各単位反応について，おのおの の酸素分圧 $P_{\mathrm{O}_{2}}(\mathrm{Fe}), P_{\mathrm{O}_{2}}(\mathrm{Si}), P_{\mathrm{O}_{2}}(\mathrm{P})$ を考兄ると，そ れらは次のようにして求められる.

$$
\begin{aligned}
& \log P_{\mathrm{O}_{2}}(\mathrm{Fe})=\Delta G(\mathrm{Fe}){ }^{\circ}{ }_{59} / 2.3 R T+2 \log a_{\mathrm{FeO}} \cdots(62 \\
& \log P_{\mathrm{O}_{2}}(\mathrm{P})=\Delta G(\mathrm{P}){ }_{60}^{\circ} / 2.3 R T+4 / 5 \log a_{\mathrm{PO2.5}} \\
& \log a_{\mathrm{PO}_{2.5}} / a_{\mathrm{P}}
\end{aligned}
$$

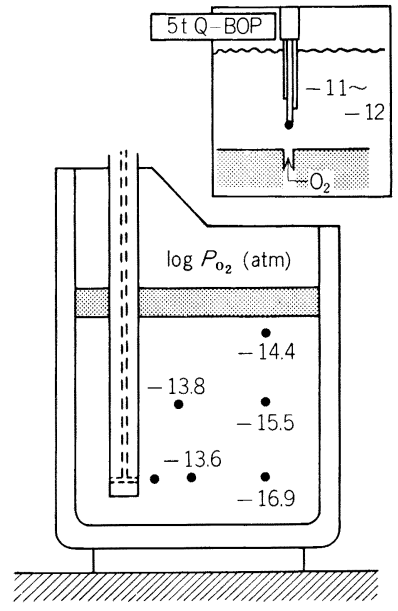

図 $9 \mathrm{a}$ ） 溶銑中の $P_{\mathrm{O}_{2}}$ 分布

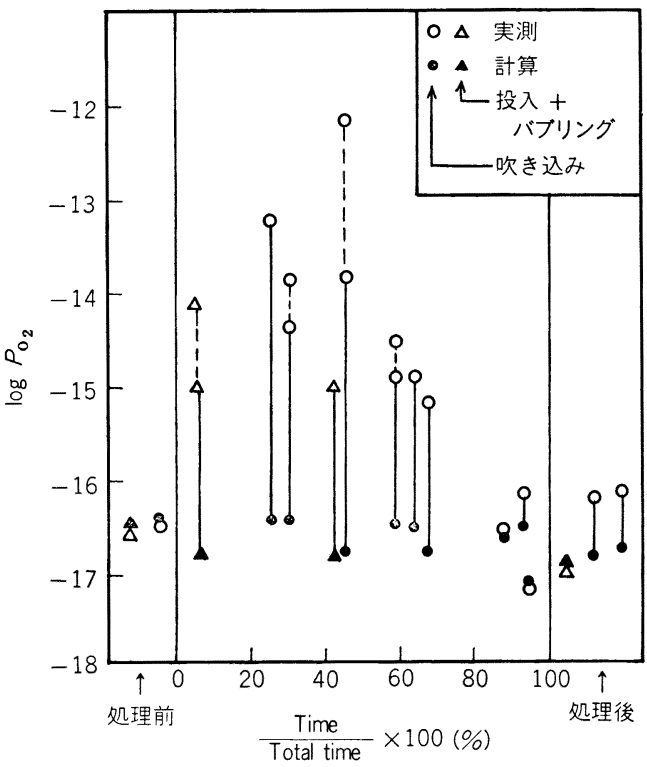

図 $9 \mathrm{~b}$ ）処理前後および処理中のトップスラグ/溶 銑界面近傍の $P_{\mathrm{O}_{2}}$

$$
\log P_{\mathrm{O}_{2}}(\mathrm{Si})=\Delta G(\mathrm{Si}){ }_{61}^{\circ} / 2 \cdot 3 R T+\log a_{\mathrm{SiO}_{2}} / a_{\mathrm{Si}}
$$

混成電位に対してはスラグーメタル界面の酸素分圧 $\left(\left(P_{\mathrm{O}_{2}}\right)\right.$ と表わす $)$ を対応させる.

図 9 a) は， $\mathrm{O}_{2}$ 吹き込みによる予備脱りんの時期に 酸素濃淡電池で測定したメタル中の $P_{\mathrm{O}_{2}}$ の分布およびス ラグーメタル界面近傍の $P_{\mathrm{O}_{2}}$ の変化の例を示す ${ }^{51)}$. 処理 中でもノズルより離れたメタル内では, $P_{\mathrm{O}_{2}}(\mathrm{C})(\mathrm{C}+$ $1 / 2 \mathrm{O}_{2}=\mathrm{CO}, a_{\mathrm{C}}=1, P_{\mathrm{CO}}=1 \mathrm{~atm}$ でちられる)に近い. しかし, 処理中のスラグ-溶鉄界面の $\left(P_{\mathrm{O}_{2}}\right)$ は図 $\left.9 \mathrm{~b}\right)$ の ように $P_{\mathrm{O}_{2}}(\mathrm{C})$ よりは大きく離れ, $P_{\mathrm{O}_{2}}(\mathrm{Fe})$ に近いと考 えられる. 石黒ら ${ }^{52}$ 恃図 10 のように，転炉内で攪汼の 


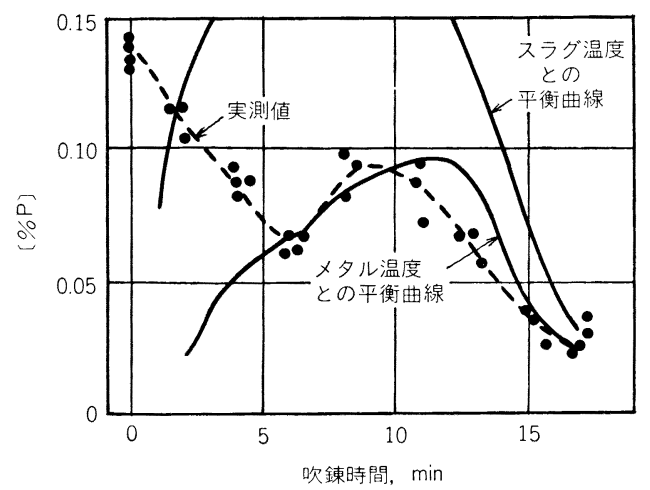

図10 転炉吹鍊中の $\mathrm{P}$ の挙動

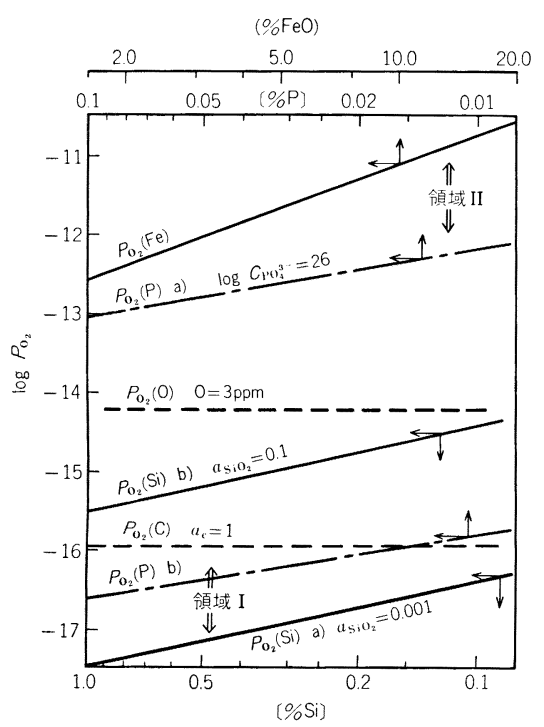

図 $11 \mathrm{FeO} / \mathrm{Fe}, \mathrm{SiO}_{2} / \mathrm{Si}, \mathrm{PO}_{2.5} / \mathrm{P}, \mathrm{CO} / \mathrm{C}$ の示す 酸素分圧と成分濃度の関係

強化される中期以後, 刻々のPの分配比がその時々のス ラグ中 $\mathrm{FeO}$ 濃度の与える酸素分圧で決まる值を示しつ つ推移することを見出した. この現象は部分平衡の状態 とみなされ，スラグーメタル界面の酸素分圧 $\left(P_{\mathrm{O}_{2}}\right)$ は $P_{\mathrm{O}_{2}}$ (Fe) に近いことを予想させる.

また, 高炉の炉床反応の解析でも, $\left(P_{\mathrm{O}_{2}}\right)$ は炉内の二 一クス大過剰の状態から期待される $P_{\mathrm{O}_{2}}(\mathrm{C})$ よりはかな り高いことが推定されている53)35)。 このように， $\left(P_{\mathrm{O}_{2}}\right)$ が $P_{\mathrm{O}_{2}}(\mathrm{C})$ からずれる傾向を示すのは, $\mathrm{CO}$ ガス発生 反応が核発生を伴らため, 他のスラグーメタル反応に比 ベ遅いことに起因しているようである54).

これらの関係をより定量的に表現する目的で, 図 11 に(62)〜(64)などの式を用いて， $1450^{\circ} \mathrm{C}$ における各反 応の $P_{\mathrm{O}_{2}}$ を濃度の関数として示した. $\mathrm{CaO}$ を主体と する高塩基スラグ $\left(\gamma_{\mathrm{FeO}}=2, \quad \log C_{\mathrm{PO}_{4}}{ }^{3-}=26, \quad a_{\mathrm{SiO}_{2}}=\right.$

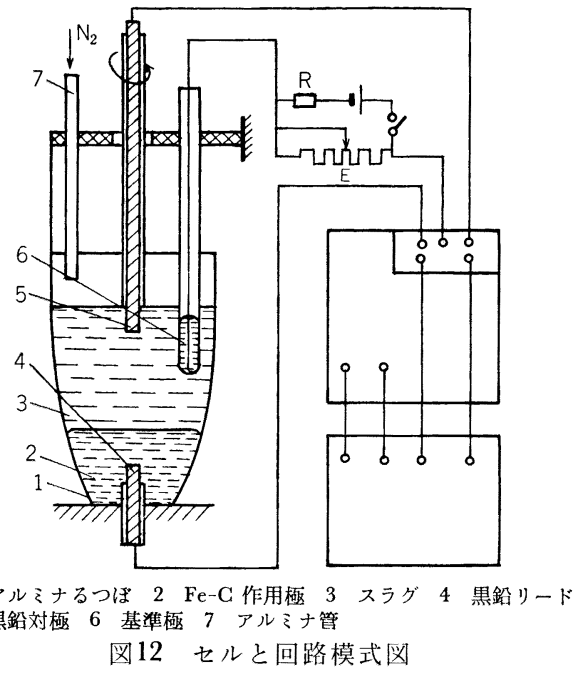

0.001 とした）を用いた場合，図中の直線 a ）に見るよ らに，通常の溶銑濃度範囲では $P_{\mathrm{O}_{2}}(\mathrm{Si})$ は $P_{\mathrm{O}_{2}}(\mathrm{C})$ よ りもかなり低い.したがつて，このような条件ではスラ グーメタル界面の $\left(P_{\mathrm{O}_{2}}\right)$ は $P_{\mathrm{O}_{2}}(\mathrm{Si})$ の影響を受けてその 近くまで低下し（図中領域 I ）. 平衡論的にも $\mathrm{G}$ に対す る $\mathrm{Si}$ の優先酸化が進行する.

Si の濃度がかなり下がつてくると, $P_{\mathrm{O}_{2}}(\mathrm{Si})$ の $\left(P_{\mathrm{O}_{2}}\right)$ に対する支配力は弱まつて, $\left(P_{\mathrm{O}_{2}}\right)$ は $P_{\mathrm{O}_{2}}(\mathrm{Fe})$ の方へ ずれていくと考えられる．実際に，溶銑中の $a_{\mathrm{O}}$ を固体 電解質を用いて測定した結果では, 多くの場合, 平衡値 よりる過剩の酸素の溶解が認められている ${ }^{55)}$. このこと は，溶銑の $P_{\mathrm{O}_{2}}$ が $\mathrm{C} て ゙$ 決まる $P_{\mathrm{O}_{2}}(\mathrm{C})$ ではなくて， $a_{\mathrm{O}}$ に対応する $P_{\mathrm{O}_{2}}(\mathrm{O})\left(1 / 2 \mathrm{O}_{2}=\mathrm{O}\right.$ より求める) の值まで, 引き上げられていることを示している. その結果, $\left(P_{\mathrm{O}_{2}}\right)$ はたとえば，図の破線 $\left(a_{\mathrm{O}}=3 \mathrm{ppm}\right)$ 付近に 位置して， 直線 $\mathrm{b})$ のような中性スラグ $\left(a_{\mathrm{SiO}_{2}}=0.1\right)$ によつても, 脱珪が優先的に進行することになる.

一方, $P_{\mathrm{O}_{2}}(\mathrm{P})$ は一点鎖線 a ) にみるように, 更に高 い.したがつて, $\left(P_{\mathrm{O}_{2}}\right)$ がいつそう $P_{\mathrm{O}_{2}}(\mathrm{G})$ から離れ, $P_{\mathrm{O}_{2}}(\mathrm{Fe})$ に近い領域II 至つて初めて, 脱りんが進行す

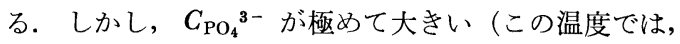
$\log C_{\mathrm{PO}_{4}}{ }^{3-}$ が 31 以上, $f_{\mathrm{P}_{2} \mathrm{O}_{5}}$ にして $5 \times 10^{-29}$ 以下) フラックスであれば，鎖線 $\mathrm{b} ）$ にみるように $P_{\mathrm{O}_{2}}(\mathrm{P})$ を $P_{\mathrm{O}_{2}}(\mathrm{C})$ より下げることができ, 平衡論的にも $P$ の優 先酸化が進及得る. $\mathrm{Na}_{2} \mathrm{CO}_{3}$ 単味の場合, この条件が 満足されている可能性がある ${ }^{56)}$.

$3 \cdot 2 \cdot 2$ 界面電位の測定

反応が進行中のスラグーメタル界面の電位, すなわち, 上述の $\left(P_{\mathrm{O}_{2}}\right)$ が実測できれば, 反応経過を知るためのモ ニターとして有用であろら。

EsIN らは図 12 のよらなセルを組んで脱硫反応の経 過を測定している ${ }^{57) 58)}$. 
表 3 図 13 の計算に用いたパラメータの数值

\begin{tabular}{|c|c|c|c|c|c|c|c|c|c|c|c|c|}
\hline 番号 & & & $\overline{\bar{a}} / \mathrm{SiO}_{2}$ & 2) & & ${ }^{\left({ }^{\circ} \mathrm{C}\right)^{\text {度 }}}$ & $\log C_{\mathrm{PO}_{4}}{ }^{3-}$ & $\log C_{\mathrm{s}^{2-}}$ & $\log K_{\mathbf{P}}$ & $\log K_{\mathrm{s}}$ & $f_{\mathrm{P}}$ & $f_{\mathrm{S}}$ \\
\hline (1) & 高 & 妒 & $\begin{array}{c}\pi \\
(1.0)\end{array}$ & ラ & $\eta^{\prime \prime}$ & 1400 & 18 & -4.0 & 4.8 & 3.0 & 3.0 & 4. 2 \\
\hline (2) & LD & 転 & 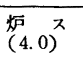 & $\overline{\text { ज }}$ & $n^{\circ}$ & 1400 & 21 & -2.5 & 4. 8 & 3.0 & 3.0 & 4.2 \\
\hline (3) & LD & 転 & 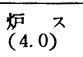 & ラ & グ & 1650 & 17 & -2.5 & 4. 3 & 2.4 & 1.0 & 1.2 \\
\hline (4) & $30 \mathrm{Ca}$ & $\mathrm{aO}-7$ & $0 \mathrm{CaCl}_{2}$ & & & 1400 & 23 & -1.0 & 4.8 & 3.0 & 3.0 & 4. 2 \\
\hline
\end{tabular}

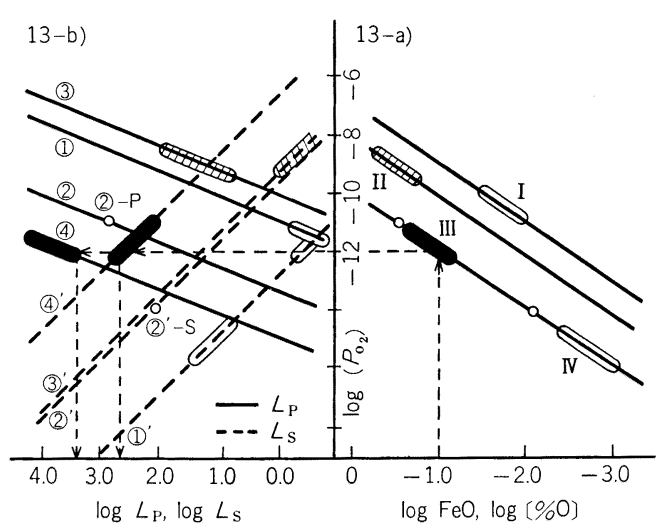

図13 分配比と $\left(P_{\mathrm{O}_{2}}\right)$ の関係

最近, 永田らは59)らは固体電解質を組みこんだセルで $\left(P_{\mathrm{O}_{2}}\right)$ 測定を試みており， $\mathrm{Na}_{2} \mathrm{CO}_{3}$ を用いた脱りん反 応に適用し, $\left(P_{\mathrm{O}_{2}}\right)$ が炭素飽和溶鉄中の $P_{\mathrm{O}_{2}}$ よりも低 くなる現象を観察している.これと図 11 の鎖線 $\mathrm{b})$ な どの関係が明らかになることにより， スラグーメタル反 応機構の解明がいつそら進展することが期待される.

\section{3 分配比}

$3 \cdot 3 \cdot 1$ 同時脱硫脱りん反応の平衡論的条件

$C_{\mathrm{S}^{2-}}{ }^{2-} C_{\mathrm{PO}_{4}}{ }^{3-}$ が既知のスラグを用いた場合につい て脱硫扣よび脱りん反応の同時的進行を可能とする平衡 論的条件について考察する ${ }^{50)}$. その場合の前提条件は次 のようなものである.

1 ) 脱りん反応は (16)式, 脱硫反応は次式で記述でき る.

$\mathrm{S}+\mathrm{O}^{2-}=\mathrm{S}^{2-}+1 / 2 \mathrm{O}_{2}$

2) したがつて脱りん反応の分配比 $L_{\mathrm{P}}$ はスラグーメ タル界面の酸素分圧 $\left(P_{\mathrm{O}_{2}}\right)$ の $5 / 4$ 乗に, 脱硫反応の $L_{\mathrm{S}}$ は $\left(P_{\mathrm{O}_{2}}\right)$ の $-1 / 2$ 乗に比例し, おのおの $(6)$ およ び(5)式で表現できる.

$3)\left(P_{\mathrm{O}_{2}}\right)$ は原則として $(62)$ 式で与えられる. これらの前提のもとに分配比 $L_{\mathrm{P}}$ および $L_{\mathrm{S}}$ と $\left(P_{\mathrm{O}_{2}}\right)$ の関係を求めると図 13b) が得られる60).

図に拈いて，たとえば LD スラグ $(\mathrm{C} / \mathrm{S}=4)$ を用い て溶鋼の脱りん脱硫を行う場合 $\left(1650^{\circ} \mathrm{C}\right), \log L_{\mathrm{p}}$, $\log L_{\mathrm{S}}$ と $\log \left(P_{\mathrm{O}_{2}}\right)$ の関係は表 3 の数值と (5), (6)式

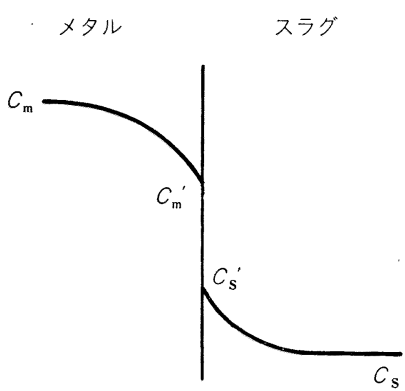

図14 スラグーメタル界面の二重境膜モデル

より(3)および(3)' の直線で表される. スラグ中の $\mathrm{FeO}$ 濃度が $10 \sim 30 \%$ に対応する $a_{\mathrm{FeO}}$ が $0.2 \sim 0.6$ の場 合, 相当する $\log P_{\mathrm{O}_{2}}$ は図 a) の領域IIで, その時実現 され得る分配比の範囲が直線 (3), (3)'上で DIDDDDオ で示されている. これによれば，脱りんは十分に進行し 得るが，脱硫は期待できないことになる.

一方，たとえば， $\mathrm{CaO}-\mathrm{CaCl}_{2}$ フラックスを用いた場 合は, 図中に矢印の点線で示したごとく，図a)の領域III と図b) の(4)および(4) の上の黒ぬりの範囲で示され， $L_{P}$, $L_{\mathrm{S}}$, ともに高い值の得られる可能性がある. すなわち, $C_{\mathrm{S}^{2-}}{ }^{2-} C_{\mathrm{PO}_{4}{ }^{3-}}{ }^{3-}$ ともに高いスラグを用いれば，同時に脱 りん脱硫反応を進めることは平衡論的に容易である.

他方, 現実の炉内を考えると, 炉内全域にわたつて, $\left(P_{\mathrm{O}_{2}}\right)$ が一様である場合は少なく, 反応条件に応じて炉 内には $\left(P_{\mathrm{O}_{2}}\right)$ の分布がある. したがつて, この $\left(P_{\mathrm{O}_{2}}\right)$ の分布を利用して，たと竞ば (2)，(2) の系で言えば，(2) -P の領域で脱りん反応を(2)'-S の領域で脱硫反応を進 行させることができれば，同一処理時に脱りん脱硫を同 時に進行させることが可能であろら.

これは反応装置の機能分化を意味し， $\left(P_{\mathrm{O}_{2}}\right)$ の異なる (2) $-\mathrm{P}$, (2)'-S の領域を独立に制御し 得る反応装 置の設 計により, キャパシティの極端に大きくはないスラグに よつても平衡論的には十分な精錬効果が期待できること を示している.

$3 \cdot 3 \cdot 2$ 総括反応速度に対する効果

i ）総括物質移動係数； スラグーメタル反応の 総括 的な速度過程を図 14 のような二重境膜モデルで表現す ると，その総括速度は次式で表される。 


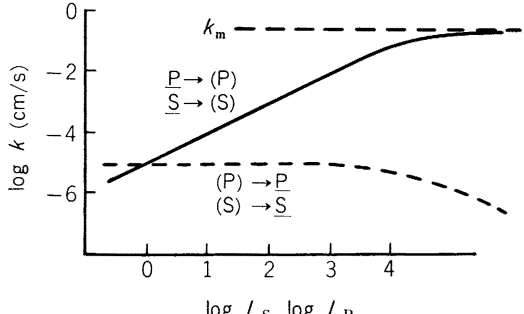

$\log L_{\mathrm{S}}, \log L_{\mathrm{P}}$

㬰線は脱りん，脱硫方向の速度係数 点線は復りん, 復硫方向の速度係数

図15 総括物質移動係数に及ぼす分配比の影響

表 4 各種スラグの粘性值例

\begin{tabular}{|c|c|c|c|c|c|c|c|}
\hline 温度 & $\mathrm{CaO}$ & $\mathrm{SiO}_{2}$ & $\mathrm{Al}_{2} \mathrm{O}_{3}$ & $\mathrm{CaF}_{2}$ & $\mathrm{Fe}_{2} \mathrm{O}_{3}$ & 粘度 $\mu$ & 文 \\
\hline$\left({ }^{\circ} \mathrm{C}\right)$ & & (\%) & & & & (poise) & 献 \\
\hline $\begin{array}{l}1500 \\
1500 \\
1500 \\
1500 \\
1500 \\
1500 \\
1500 \\
1450 \\
1450 \\
1400 \\
1400\end{array}$ & $\begin{array}{l}40 \\
50 \\
50 \\
44 \\
50 \\
30 \\
23 \\
20 \\
36 \\
40 \\
23\end{array}$ & $\begin{array}{l}10 \\
20 \\
10 \\
20 \\
10\end{array}$ & $\begin{array}{l}20 \\
40 \\
\\
36\end{array}$ & $\begin{array}{c}60 \\
54\left(\mathrm{CaCl}_{2}\right)\end{array}$ & $\begin{array}{c}70 \\
67 \\
\\
40(\mathrm{FeO}) \\
67\end{array}$ & $\begin{array}{c}9.2 \\
5.0 \\
4.0 \\
1.5 \\
0.5 \\
0.22 \\
0.25 \\
0.4 \\
<0.1 \\
4.0 \\
0.30\end{array}$ & $\begin{array}{l}(61) \\
(61) \\
(61) \\
(62) \\
(62) \\
(61) \\
(61) \\
(62) \\
(63) \\
(61) \\
(61)\end{array}$ \\
\hline
\end{tabular}

$d[\% i] / d t=k A / V_{\mathrm{m}} \cdot([\% i]-(\% i) / L(\%)) \cdots(66)$ ここに, $L(\%)=(\% i) /[\% i]$ は\%表示による分配比で ある（ $i=\mathrm{P}$ の場合， $(\% i)$ は $\mathrm{PO}_{4}$ として算出してい る). $V_{\mathrm{m}}$ は溶鋼の体積, $A$ はスラグーメタル界面積であ る. $k$ は総括物質移動係数で, 図 14 のモデルの場合, 次式で表される.

$$
k=1 /\left(1 / k_{\mathrm{f}}+1 / k_{\mathrm{m}}+1 / k_{\mathrm{s}} L\right)
$$

ここに $k_{\mathrm{f}}$ は化学反応速度係数, $k_{\mathrm{m}}, k_{\mathrm{s}}$ はおのおのメタ ル，スラグ相に打ける物質移動係数，Lはモル濃度で表 現した分配比 $\left(L=\rho_{\mathrm{S}} / \rho_{\mathrm{m}} \cdot M_{\mathrm{i}}{ }^{(\mathrm{m})} / M_{\mathrm{i}}{ }^{(\mathrm{S})} \cdot L_{\mathrm{i}}(\%)\right)$ である.

分配比に対して，(5)，(6)式の一般的表現

$$
L_{\mathrm{i}}=C_{\mathrm{i}} \cdot f_{\mathrm{i}} \cdot\left(P_{\mathrm{O}_{2}}\right)^{\mathrm{n}}
$$

を用いると， $k_{\mathrm{f}}>>k_{\mathrm{m}}, k_{\mathrm{s}}$ とみなせる条件では，

$$
d[\% i] / d t=k A / V_{\mathrm{m}} \cdot\left([\% i]-(\% i) / C_{\mathrm{j}} f_{\mathrm{i}}\left(P_{\mathrm{O}_{2}}\right)^{\mathrm{n}}\right)
$$

$$
k=1 /\left(1 / k_{\mathrm{f}}+1 / k_{\mathrm{m}}+1 / k_{\mathrm{S}} C_{\mathrm{j}} f_{\mathrm{i}}\left(P_{\mathrm{O}_{2}}\right)^{\mathrm{n}}\right.
$$

(70)式は，スラグーメタル反応系の 総括物質移動係数 はスラグ, メタル両相の物性に直接依存する $k_{\mathrm{m}}$ や $k_{\mathrm{s}}$ ばかりでなく, 分配比（刻々の駆動力に対応する）自身 によつても影響されることを示している，とくに， $k_{\mathrm{m}}$ $>>k_{\mathrm{s}} \cdot L$ であるために,

$$
k \sim k_{\mathrm{s}} \cdot L=k_{\mathrm{s}} \cdot C_{\mathrm{i}} \cdot f_{\mathrm{i}}\left(P_{\mathrm{O}_{2}}\right)^{\mathrm{n}}
$$

とみなせる条件（反応速度が比較的小さい条件）では, 総括物質移動係数が分配比の影響ををともに受けて，ス ラグの物性とは直接関係のない界面の酸素分圧に大きく 依存することになる（たとえば，脱りん速度が $(\% \mathrm{FeO})$ に直接依存する場合).

図 15 に, 総括物質移動係数 $k$ と分配比および $\left(P_{\mathrm{O}_{2}}\right)$

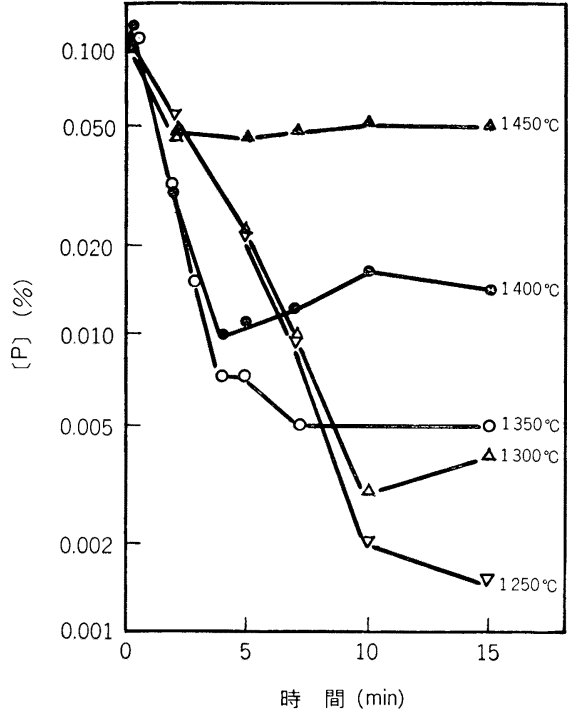

図16 $\mathrm{Na}_{2} \mathrm{CO}_{3}$ による脱りえ速度に対する温度の影 響 $\left(\mathrm{Na}_{2} \mathrm{CO}_{3} 30 \mathrm{~kg} / \mathrm{t} \cdot\right.$ 溶銑, $\left.\mathrm{Si}=0.15 \%\right)$

の関係を模式的に示した. 分配比増大につれ, $k_{\mathrm{s}} \cdot L$ が相 対的に大きくなつて混合律速領域に入り, 分配比が十分 に大きくなる条件を選べば，総括物質移動係数は $k_{\mathrm{m}}$ で 飽和し，溶鉄側の物質移動が全過程を律速することにな 万 $5^{32}$.

ii ）総括物質移動係数に対する粘性の効果； 物質移 動係数は定常状態における境膜モデルでは，

$$
k=D / \delta
$$

で表現される. ここに，D拡散係数, $\delta$ は境膜厚さで あり, 粘性係数の関数になる.

さらに，回転円板などの固体からの液体中への物質移 動では，次式のよらな関係が成立する.

$$
S h=\alpha \cdot S \mathrm{c}^{\mathrm{a}} \cdot \operatorname{Re}^{\mathrm{b}}
$$

ここに, $S h=k l / D$ (シャーウッド数), $S \mathrm{c}=\mu / \rho D$ (シュ ミット数), $\operatorname{Re}=l u / D$ (レイノルズ数), $\mu$ : 粘性係数 であり, (73)式中で, $a=1 / 3, b=1 / 2$ となる場合が多 い. この時は,

$$
k \propto D^{2 / 3} \cdot \mu^{1 / 6}
$$

このように, 物質移動係数は $D^{\mathrm{a}}$ に比例, $\mu^{\mathrm{b}}$ に反比 例し， $a, b$ は流体力学的条件により変わるが，一方, $D, \mu$ は液体の構造を直接反映する. とくにスラグの $\mu$ は, 表4にみられるように, 組成により大幅に異なる. $\mathrm{SiO}_{2}$ や $\mathrm{Al}_{2} \mathrm{O}_{3}$ の高い系では粘性は高く, $\mathrm{CaF}_{2}, \mathrm{CaCl}_{2}$ の多い系では低い。とくに，後者の場合は，メタル相に 匹敵する程低い粘性を有する．温度の効果は， $\mu=\mu_{0} \exp$ $\left(E_{\mu} / R T\right)$ で表現されるように大きいので一般に融点を 下げる添加物は粘性低下に有効である.

図 16 は, $\mathrm{Na}_{2} \mathrm{CO}_{3}$ による溶銑の脱りん速度に対す る温度の影響を示している ${ }^{64)}$. 温度上昇は $C_{\mathrm{PO}_{4}}{ }^{3-}$ に大 


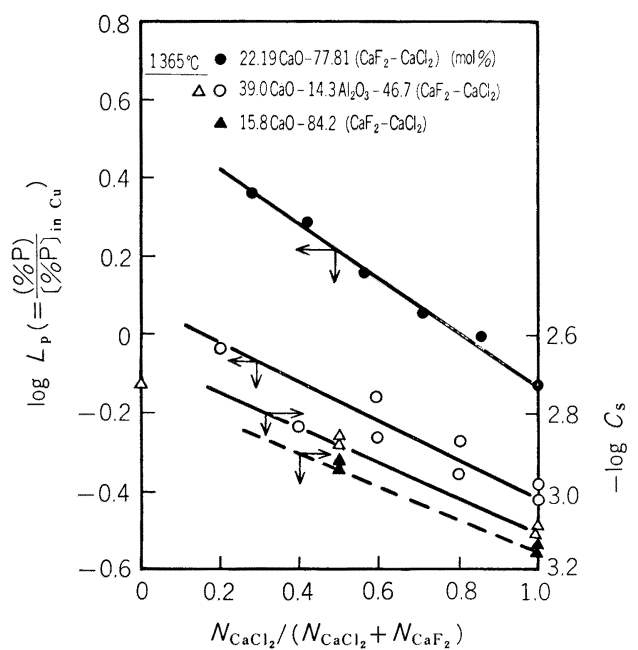

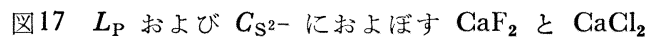
の混合比の影響

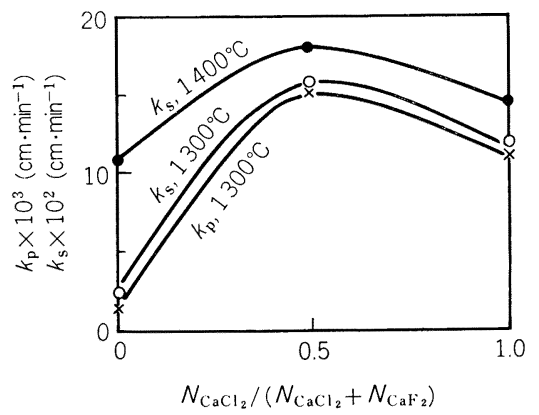

図18脱硫および脱りえの速度係数におよぼす

$\mathrm{CaF}_{2}$ と $\mathrm{CaCl}_{2}$ の混合比の影響

きく影響し，(70)式により $k$ を下げるが，他方，粘性も 大幅に低下して $k_{\mathrm{s}}, k_{\mathrm{m}}$ の増大をもたらす. 図では, 初 期の脱りん速度は温度の高い方が大きくなつており， $k_{\mathrm{s}}, k_{\mathrm{m}}$ の増大効果が $C_{\mathrm{PO}_{4}}{ }^{3-}$ への減少効果を上回つて いることを示している.

また，図 17 は, $\mathrm{GaO}$ に対して $\mathrm{CaF}_{2}$ または $\mathrm{CaCl}_{2}$ を添加した時の分配比 $L_{\mathrm{P}}$ (溶融銅に対する) とサルファ イド・キャパシティ増大効果を比較している25b). 脱硫, 脱りんのいずれの場合も， $\mathrm{CaF}_{2}$ の方が優位であること を示している，それにもかかわらず， $\mathrm{CaF}_{2}$ のある量を $\mathrm{CaCl}_{2}$ に置換した方が，総括反応速度は高くなることを 図 18 は示している. $\mathrm{CaCl}_{2}$ の添加は, 融点を大幅に下 ゲ，粘性の低下効果は $\mathrm{CaF}_{2}$ の場合よりははるかに大き く, 物性面での優位性が発揮された例と言える.

iii）総合的効果の検討；現実の反応系では，攪拌な ぞの流体力学的要因が反応の促進に大きく寄与してい る. そのような系で, 分配比や物質移動俰数などの物理 化学的要因がぞのように影響するかを，単純なモデルを

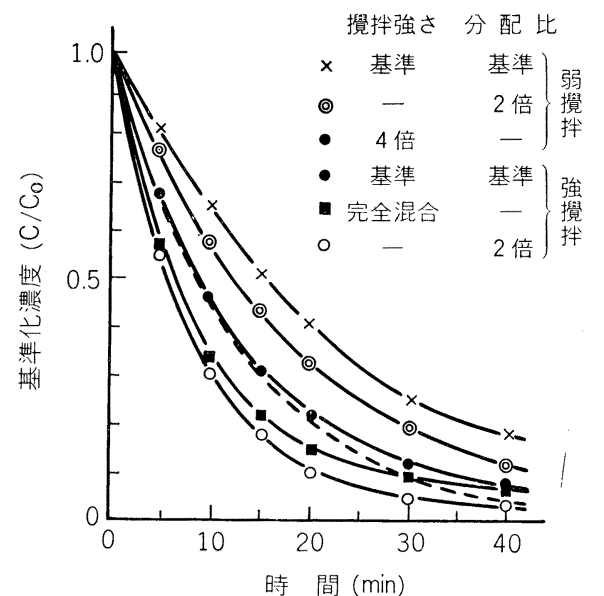

図19 総括反応速度に及ぼす擋挷条件と分配比の関 係の一例

用いて検討した．その結果を図 19 に示した ${ }^{50)}$.

摫拌の弱い状態 $(\times)$ では，摫找を強化する方 $(\rightarrow \mathbf{O})$ が分配比を 2 倍にする $(\rightarrow$ ○) よりも反応促進効果の大 きいことが分かる，一方，翼拌の強い状態（の）では,

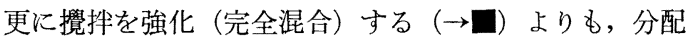
比を 2 倍 $(\rightarrow$ O) にする方が促進効果は大きい.

また，図中，点線は，基準条件（の）に対して，スラ グを 2 倍量用いた場合で，それによる反応界面積の増加 が無ければ，初期速度には影響せず，到達反応率の及が 向上することを示している.

このように，反応条件と目的に応じて，変更すべき操 業因子の優先度と選択範囲が変わり，とくに攂汼が強い ほど，総括反応速度に対する分配比の効果が顕著になる ので，スラグの選択や $\mathrm{FeO}$ 濃度など分配比への影響度 の大きな因子の制御が重要な意味をるつてくる.

\section{4. おわりに}

溶銑処理の流れを追い，その底にある物理化学的概念 の発展を追らことで, 現状の把握と将来の課題の抽出を 意図したが，筆者の力不足で，極めて一面的な流れの記 述に止まつた。しかし，確実に言えることの一つは，溶 銑処理に関する基本戦略は，スラグーメタル反応に関し ては十分に確立されているといらことであろう.

今後は，(1)たと党ば本稿では汪とんど触れることがで きなからたが，溶銑処理プロセスでは最大の関心事の一 つである $\mathrm{Na}_{2} \mathrm{CO}_{3}$ などを含む特殊な系に関する状態図 や熱力学データの蓄積, 充実, (2)粘性などの物性データ の蓄積を行い，(3)目的に応じた組成を設計し得るような 予測式を得るためのデータ・バンク機能の強化と理論的 研究を発展させること, 更に, (4)耐火物との反応など, 溶銑処理プロセスのハードの面での制約要因に対して, 物理化学的研究手法を発展させることが重要であろう. 


\section{交献}

1) L. BECK，中沢護人訳：鉄の歴史（1968〜) [たた ら書房]

2) I. Lowthian BeLl: Principles of the Manufacture of Iron and Steel (1884) [George Poutledge \& Sons, London]

3 ) H. Schenck: Physikalische Chemie der Eisenhuttenprozesse. Bd. 2, (1932) [Verlag Julius Springer, Berlin]

4) T. Turner: The Metallurgy of Iron, 4 th ed. (1915) p. 47 [Charles Griffin \& Co., London]

5 ) 交献 1). IV. No. 2, p. 179

6)「わが国に打ける酸素製鋼法の歴史」鉄鋼科学・技 術史委員会，製鋼ワーキンググループ，（1981） p. 350 [日本鉄鋼協会]

7 ) 交献 1). IV. No. 1, p. 250

8 ) 交献 2). p. 360 , p. 395

9 ) 大石源治: 金属の研究, 3 (1926), p. 377

10) T. B. Winkler and J. Chipman: Trans. Metall. Soc. AIME, 167 (1946), p. 111

11) $N . J$. Grant and $J$. Chipman : Trans. Metall. Soc. AIME, 167 (1946), p. 134

12) G. $N$. Lewis and $M$. Randall: Thermodynamics, 1923, [McGraw-Hill Co.]

13) J. Chipman: Trans. ASM, 22 (1934), p. 385

14) 的場幸雄: 鉄と鋼, 20 (1934), p. 837

15）佐野幸吉：金属の研究，13 (1936)， p. B 39

16) C. Wagner: Thermodynamics of Alloys (1952), [Addison-Wesley]

17）萬谷志郎：第 42 回西山記念技術講座（日本鉄鋼 協会編）(1976.11)，p. 69

18) F. D. Richardson: Physical Chemistry of Melts in Metallurgy (1974) p. 292 [Acad. Press]

19) L. Pauling: The Nature of the Chemical Bond (1938); 小泉正夫訳：化学結合論 (1942) [共立出版]

20) P. Herasymenko: Trans. Faraday Soc., 34 (1938), p. 1246

21) H. Lux: Z. Elektrochem., 45 (1939), p. 303

22) A. Diezel: Z. Elektrochem., 48 (1942), p. 9

23) C. J. B. Fincham and $F . D$. Richardson : Proc. Roy. Soc., A 223 (1954), p. 40

24）鉄鋼便覧（日本鉄鋼協会編）基礎編 (1981)， p. 61

25） a ）的場幸三：東北大学工学修士論交 (1978);

b) 橋本雅弘：東北大学工学修士論文 (1983);

c) 橋本雅弘, 井上博文, 大谷正康, 寺島清隆: 鉄と鋼，68 (1982), S. 959

26) $R$. Inoue and $H$. Suito: Trans. ISIJ, 22 (1982), p. 514

27) C. Wagner: Metall. Trans., 6 B (1975), p. 405

28) 伊藤公久: 東京大学工学博士論文 (1983)

29）川合保治，土居定雄，森 克已：鉄と鋼，63 (1977)，p. 391

30）岩崎克博, 佐野信雄, 松下幸雄: 鉄と鋼, 67 (1981)，p. 536

31) 水渡英昭, 井上 亮, 高田 稔：鉄と鋼， 67 (1982), p. 2645

32）竹之内朋夫，鈴木是明：鉄と鋼，64（1978） p. 1133

33) T. B. King and $S$. Ramachandran: The Physical Chemistry of Steelmaking, MIT Symposium (1958), p. 125 [Wiley]
34) $K$. Koch, G. Tromel, and G. Heinz: Arch. Eisenhüttenwes., 46 (1975), S. 83

35) E. T. Turkdogan, G. T. Kor, and $R . J$. FRUEHAN: Ironmaking and Steelmaking, 6 (1980), p. 268

36) $M$. Tokuda and $M$. Ohtani: Chemical Metallurgy of Iron and Steel, Proc. Internat. Symp. Met. Chem. (1971), Sheffield

37) 德田昌則：金属学会会報, 15 (1976), p. 6

38) $H$. Inoue, $Y$. Shigeno, $M$. Tokuda, and $M$. Ohtani: SCANINJEGT II. (1980), No. 19

39) 横川敏雄：鉄と鋼, 68 (1982), p. 26

40) 内藤圭爾, 野村真三: 電気化学, 35 (1967), p. 319; 増子 昇: 同, p. 508; 後藤和弘, 松下 幸雄：同，p. 514

41) R. Didtschenko and E. G. Rochow: J. Am. Chem. Soc., 76 (1954), p. 3291

42) M. Tokuda and Ohtani: Proc. Int. Conf. Sci. Tech. Iron Steel, Suppl. Trans. ISIJ. vol. II (1971), p.575

43）森 一美：鉄と鋼，46 (1960), p. 466

44) G. H. Frischat and G. TomandL: Glastechn. Ber., 42 (1969), p. 182

45) C. H. P. Lupis, L. Pargamin, and P.A. Flin: Metall. Trans., 3 (1972), p. 2093

46) 森永健次, 杉之原幸夫，柳ケ瀬勉：日本金属学会 誌, 40 (1976), p. 480

47) J. A. Duffy and M.D. Ingram: J. Non-Gryst. Solids, 21 (1976), p. 373

48) D. R. Gaskell: Trans. ISIJ, 22 (1982), p. 997

49) $S$. Sumita, $Y$. Matsumoto, $K$. Morinaga, and T. YANAGASE: Trans. JIM., 23 (1982), p.360

50) 大谷正康, 德田昌則, 井上博文: 学振 19 委No. 10378 (昭和 56 年 10 月)

51）竹内秀次，小沢三千晴，野崎 務，江見俊彦，大 久保雅一, 大谷尚史：鉄と鋼, 68(1982), p.S 1026

52）石黑守幸，宮下芳雄，根本秀太郎：鉄と鋼，57 (1971), S 267

53) $N$. Tsuchiya, $M$. Tokuda, and $M$. Ohtani: Metall. Trans., 7 B (1976), p. 315

54) L. S. Darken and $R$. W. Gurry: Physical Chemistry of Metals (1953) [McGraw-Hill Co.]

55）山田健三, 岩崎克博, 中村博巳, 山瀬 治, 栗山 伸二，小倉英彦：鉄と鋼, 68 (1982), S 955

56）中島義夫, 向坂 登, 森谷尚玄：鉄と鋼， 68 (1982), S 954

57) $V . S$. Shantarin, $O . A$. Esin, and $V . N$. Boronenkov: IZV. AN SSSR, Met., (1968) 5, p. 18

58) G. $A$. Toporisiahev, $A . S$. Ghyrkin, $V . N$. Boronenkov, and $O$. A. EsIN: IZV. AN SSSR, Met., (1969) 4, p. 3

59）永田和宏，後藤和弘：鉄と鋼, 68 (1982), S 17

60) M. TокudA: Reprints of Germany-Japan Seminar (1982) p. 83 [Ver. Deut. Eisenh.]

61）溶鉄，溶滓の物性值便覧（1971）［日本鉄鋼協会]

62) Schlackenatlas (1981) [Verlag Stahleisen M.B.H.]

63) 井上博文, 重野芳人, 德田昌則, 大谷正康: 鉄と 鋼, 69 (1983), p. 210

64) 山本里見, 藤掛陽蔵, 坂口庄一：鉄と鋼，68 (1982), p. 1896 